\title{
CARRERA ECLESIÁSTICA Y ALGUNOS DESLICES DE FELIPE DEL HOYO Y PEDRO CELESTINO TOMÉ, ARCEDIANOS DE BURGOS (1731-1784)
}

\author{
POR \\ Francisco J. SANZ DE LA Higuera* \\ I.E.S. «Torreblanca», Sevilla
}

\begin{abstract}
RESUMEN
Dos de los titulares del Arcedianato de Burgos en el siglo XVIII, miembros prominentes del Cabildo catedralicio de dicha ciudad, don Felipe del Hoyo Santamaría (1731-1750) y don Pedro Celestino Tomé Carrera (1751-1784), gozaron durante parte de su existencia del disfrute carnal con sendas barraganas en sus respectivas viviendas, amantes mujeres que convivieron con ellos, clérigos consagrados y dados, teóricamente, a la castidad, a la pobreza y a la obediencia, como si de cónyuges legítimas se tratara.
\end{abstract}

PALABRAS CLAVE: Mujer, Barragana, Clérigo, Arcediano, Sexualidad, Catedral.

\section{«ARCHDEACONS OF BURGOS (1731-1784). FELIPE DEL HOYO AND PEDRO CELESTINO TOMÉ'S ECCLESIASTICAL CAREER AND HUMAN MISTAKES»}

\begin{abstract}
Two of the titulars of the Arcedianato of Burgos in the $18^{\text {th }}$ century, prominent members of the Cathedral Council, don Felipe del Hoyo Santamaría (1731-1750) and don Pedro Celestino Tomé Carrera (1751-1784), had, during
\end{abstract}

* Dedico estas páginas, de manera pública y notoria, a Nicolás Pérez Rosado porque su amistad y su entrañable y fraternal afecto me han demostrado constantemente que hay personas buenas, trabajadoras y honradas, cuya existencia constituye una auténtica joya para la humanidad. 
part of their lives, carnal enjoyment with one «Barragana» each, in their own homes. Loving women who lived with them, established clergymen, in theory dedicated to chastity, poverty and obedience, as if were their legal wives.

KEY WORDS: Women, Barragana, Clergyman, Arcediano, Sexuality, Cathedral.

Recibido/Received 13-10-2007

Aceptado/Accepted 30-07-2008

De la documentación a que hemos tenido acceso para el discurrir vital de los arcedianos de Burgos don Felipe del Hoyo Santamaría (1731-1750) y don Pedro Celestino Tomé Carrera (1751-1784) se extraen, a mi juicio, algunas consideraciones que sugieren la existencia de algunas prácticas sospechosas, quizá evidentes, de amancebamiento, y, por tanto, de una sexualidad más o menos clandestina ${ }^{1}$.

Para llegar a las reflexiones y conclusiones que se vierten en estas páginas se ha rastreado de manera sistemática y serial en los diversos archivos de la ciudad. Ese zambullirse de forma persistente en los legajos notariales de los protocolos, recopilados y custodiados en el Archivo Histórico Provincial de Burgos (AHPB), y en la documentación del Archivo Capitular de la Catedral de Burgos (ACC), nos ha deparado la aparición de múltiples informaciones sobre el vivir y el morir de dichos clérigos, de sus familias y de algunas de las mujeres que les acompañaron a lo largo de su existencia. Son especialmente significativos sus inventarios post-mortem y sus testamentos. Del ACC proceden indicaciones de primera mano sobre sus actividades profesionales, patologías médicas, conductas irregulares, alquiler de viviendas, etc.

Una apoyatura esencial e imprescindible en el proceso de investigación y desarrollo e innovación puesto en marcha en la reconstrucción histórica es la bibliografía publicada sobre los clérigos, sus andanzas cotidianas y extraordinarias y las idiosincrasias y peculiaridades que les son atribuibles. En el Anexo bibliográfico, sito en las páginas finales, se da cuenta de las principales aportaciones a este respecto.

\footnotetext{
${ }^{1}$ En ambos casos se detecta la presencia, ocasional o estable, de mujeres en sus vidas, muy cerca de ellos, como barraganas o concubinas que vivían en la casa del que está amancebado con ella. Utilizamos la «barraganería» definida como unión estable y convivencia persistente entre hombre y mujer pero sin la categoría de matrimonio otorgado por la Iglesia y el «amancebamiento» como el trato sexual habitual entre hombre y mujer no casados entre sí. Se trata de una sexualidad clandestina y reprobable -reprobable no por el sexo en sí mismo sino porque tales prácticas incumplían uno de los votos que ellos mismos habían asumido defender y hacer efectivos también para los demás-.
}

Hispania Sacra, LXI

124, julio-diciembre 2009, 649-690, ISSN: 0018-215-X 


\section{El arcediano Pedro Celestino Tomé Carrera (1751-1784).}

Pedro Celestino fue el segundo hijo nacido en el matrimonio conformado por don Pedro Tomé González y Josefa Carrera, Castro y Castilla. Habían contraído nupcias el 25 de febrero de 1725², «Nazió dho niño el día 18 deste mes [mayo] a las tres de la mañana» y fue bautizado el día 21 en la parroquia titulada de Santiago de la Capilla. Fue su padrino, como era habitual en estos actos, el beneficiado de San Martín Juan Gómez Barrón, íntimo amigo y asiduo colaborador de Pedro Tomé ${ }^{3}$.

Su primer vástago fue Juan Manuel, nacido en enero de $1726^{4}, 10$ meses y 5 días después de la boda de sus padres. Sería el destinado a continuar los elevados quehaceres empresariales, burocráticos y políticos de los negocios familiares, a casarse y a conformar un hogar. Él asumiría su mayorazgo y el liderazgo de sus intereses. Mano derecha y lugarteniente de su progenitor durante bastantes años, un tremendo tropiezo con la Hacienda pública le catapultó a la huida precipitada, al «destierro» a tierras madrileñas y al olvido casi absoluto ${ }^{5}$. Casado con doña María Francisca de Lizárraga Ortiz y Zárate desde 1748, a mediados de 1751 aparece «en casa y compañía» de sus progenitores, con quienes articulaba un hogar múltiple, hecho habitual en las obligaciones asumidas merced a las «Capitulaciones matrimoniales» de la época ${ }^{6}$.

Su segundo hijo, Pedro Celestino, siguió la carrera eclesiástica. En el reparto de papeles habitual en los hogares del Antiguo Régimen, en el discurrir de las estrategias domésticas tendentes a «hazer tomar esttado» a sus hijos e hijas, a Pedro Celestino le tocó protagonizar la trayectoria eclesiástica, con evidentes influencias del hermano de doña Josefa, don Felipe, canónigo en la Catedral, y del antes citado don Juan Gómez Barrón. No iba a ser, sin embargo, un clérigo

2 Archivo Diocesano de Burgos (ADB). Santiago de la Capilla. Libro de matrimonios. 25 de febrero de 1725 , folio 75 a.

3 Ibídem Libro de bautismos. 21 de mayo de 1727, folio 228a. Don Juan Gómez Barrón determinó que don Pedro Tomé y su cónyuge, doña Josefa Carrera, fueran nombrados herederos universales de sus bienes, «y por su fallecimiento sus hixos y herederos». Archivo Histórico Provincial de Burgos. Protocolos Notariales (AHPB. PN). Jacinto Álvarez. Legajo 7115 (21 de junio de 1756), folios 111-112.

${ }^{4}$ Ibídem Libro de bautismos. 2 de enero de 1726, folio 219a.

${ }^{5} \mathrm{El}$ inventario post-mortem de don Pedro Tomé quedó compilado entre los legajos de Justicia Municipal, no en los más anodinos Protocolos Notariales, porque la Administración borbónica precisaba conocer qué bienes le tocaban en herencia a don Juan Manuel, tras el óbito de su padre, para cobrar las deudas ocasionadas por el affaire de las lanas de 1755. AHPB. Justicia Municipal (JM). Juan Antonio Fernández Guilarte. Legajo 977 (30 julio de 1764). Véase F. J. SANZ DE LA HigUERA, «Pólvoras, municiones, lanas, granos, bulas y papel sellado (1704-1764). Don Pedro Tomé González y la hora Navarra en el Burgos del siglo XVIII», Boletín de la Institución Fernán González (BIFG), 227 (2003), Burgos, pp. 375-411.

${ }^{6}$ Archivo de la Diputación Provincial de Burgos (ADPB). Catastro. Burgos. Libro 347, folios 92-96. 
cualquiera, beneficiado en una triste y problemática parroquia de una ciudad o de un pueblo. Estaba llamado, por los niveles de renta y de fortuna de sus padres y parientes y por los contactos de unos y de otros en la Corte y entre altos cargos de la Iglesia, a desempeñar un cargo importante en la Catedral de Burgos. En junio de 1751, lo descubrimos ausente de casa, con 24 años. Don Pedro, su padre, señaló «se Halla en la Corte Romana, en donde le Mantengo para sus pretensiones» ${ }^{7}$. ¿El destino pergeñado para su existencia era un deseo hondamente asumido por él o una imposición dramática de sus padres y de su entorno familiar? ¿Cómo llevaba Pedro Celestino sus obligaciones de parentesco y sus limitaciones eclesiásticas?

Diego fue el tercer hijo. Nació el jueves 8 de julio de 1728, «enttre diez y onze de la mañana», y fue bautizado, también en Santiago de la Capilla, tres días más tarde ${ }^{8}$. No aparece en el «Memorial» catastral de 1751. Lamentablemente no he hallado, hasta el momento presente, la partida parroquial de su defunción.

En junio de 1730 nació Antonio Felipe, el cuarto vástago. Su trayectoria vital iba a estar marcada, en principio, por la el desempeño de algún puesto en la administración del Estado. En 1751, era estudiante de Leyes, «al que mantengo en la ziudad de Valladolid para sus Cursos» ${ }^{9}$. La desaparición de la escena familiar protagonizada por su hermano Juan Manuel en 1755 le convirtió en el heredero y continuador del entramado empresarial de la familia Tomé. El que quizá hubiera sido un oscuro y casi anónimo funcionario público, alcanzó una notoriedad importante, un gran renombre, popularidad y prestigio en la ciudad de Burgos en la segunda mitad del Setecientos ${ }^{10}$.

El cataclismo fiscal y lanero de Juan Manuel posibilitó que Antonio Tomé asumiera el mayorazgo y la comandancia de los negocios familiares -en compañía siempre de su madre, doña Josefa-, de forma que elevó sus expectativas personales hasta niveles que, en primera instancia, le eran impensables. Su formación académica y universitaria le iban a ser de gran ayuda en el desempeño de los quehaceres que asumió a partir de 1755. Fue especialmente activo en la gestión y dinamización del Consulado de Burgos, en su implicación en el gobierno municipal y en el impulso a empresas industriales y laneras.

\footnotetext{
${ }^{7}$ ADPB. Catastro. Burgos. Libro 347, folios 92-96. Véase CANDAU CHACón (2001).

8 ADB. Burgos. Santiago de la Capilla. Libro de bautismos. 11 de julio de 1728, folios 235-236.

9 DPB. Catastro. Burgos. Libro 347, folios 92-96. Archivo Universitario de Valladolid. Libro 74, «Libro de Matrículas de la Facultad de Leyes» (1750), folio 10.

${ }^{10}$ F. J. SANZ DE LA Higuera, «Pólvoras, municiones, ...», BIFG, 227 (2003), pp. 375-411, «Las restauraciones del Consulado de Burgos en el siglo XVIII», Historia, Instituciones, Documentos, 29 (2002), Sevilla, pp. 429-458 y «Estando como estamos juntos y congregados en la Casa de dha Contratación como lo acostumbramos», Luces y sombras en el Consulado de Burgos», BIFG, 229 (2004), pp. 377-413.
}

Hispania Sacra, LXI

124, julio-diciembre 2009, 649-690, ISSN: 0018-215-X 
El último de los hijos de doña Josefa Carrera, Fernando, fue llevado a la parroquia de San Gill1 el 4 de mayo de 1732. El beneficiado que lo recibió anotó en el libro correspondiente "y no le bautize por aberlo echo en caso de necesidad Dn Felipe Carrera Castro y Castilla, canónigo». Se añade, «dixeron aber nazido el día 28 de abril». Padrinos de este niño fueron sus tíos don Felipe y doña Francisca, hermanos de doña Josefa ${ }^{12}$.

No aparecen en los libros de sacramentales de las parroquias más hijos después de Fernando. Hemos de suponer que fue éste un parto muy difícil y que se temió en las primeras horas por la continuidad de su vida. Es probable que doña Josefa quedara incapacitada física, o psíquicamente, para el desarrollo de más embarazos. A pesar de todo, Fernando salió adelante y se convirtió en el experto en lanas del negocio familiar. En junio de 1751, dice su padre de él «que ttanvien está en mi Casa y compañía y se le va aplicando a las Dependencias De mi casa»13. Fue el encargado de la gestión práctica de la cabaña de ovejas merinas trashumantes de los Tomé y de los quehaceres diarios del lavadero. Falleció trágicamente en 1756 en tierras de Segovia. Un matrimonio malhadado le alejó de Burgos y de casa de sus padres ${ }^{14}$. Juan Manuel fue el consejero ejecutivo, el hacedor de los grandes negocios, y Fernando, el capataz, el hombre de los detalles funcionales, cotidianos, en la empresa de obtener beneficios de las ovejas.

Este recorrido por la familia Tomé indica algunas de sus vicisitudes y trayectorias. Nótese que ninguno de los hijos de doña Josefa fue encaminado a la vida militar y, por supuesto, adviértase que toda la descendencia es masculina ${ }^{15}$. A cada uno de ellos les fueron colocando en los derroteros imprescindibles para la perpetuación de sus intereses familiares y empresariales, que pasaban por una presencia activa en el Concejo municipal y en el Cabildo catedralicio. El administrador general de la Santa Cruzada movió los hilos para que en ambas

11 En la ciudad de Burgos la adscripción parroquial era personal, de modo que cada 10 años los «parroquianos» podían solicitar su ingreso en otra parroquia. Los Tomé fueron parroquianos de San Román (1702-1718), Santiago de la Capilla (1718-1730), San Gil (1730-1742), San Martín (17421767) y Viejarrúa (1767-1781). Cfr. C. Alonso De Porres, Las parroquias en la ciudad de Burgos, Burgos, 1981, E. SAINZ RIPA, «La división de parroquias en Logroño: el paso de un régimen de adscripción voluntaria y personal al régimen de domicilio o territorial», Berceo, 100 (1981), pp. 263-305 y M. GARCÍA FERNÁNDEZ, «El territorio diocesano y la estructura parroquial», Historia de la diócesis de Valladolid, Valladolid, 1996, pp. 151-190.

12 ADB. Burgos. San Gil. Libro de bautismos. Legajo $3^{\circ} .4$ de mayo de 1732, folio 250 av.

13 ADPB. Catastro. Burgos. Libro 347, folios 92-96.

${ }^{14}$ Sobre las tensas relaciones que en ocasiones se suscitaban entre suegros y nueras, Véase M. MoRENO Alonso, Retrato de familia andaluza con Las Indias al fondo. El memorial de El Pintado (169717809), Sevilla, 2000, pp. 56-67.

15 Sabemos de la existencia y óbito de una niña, hija de pedro Tomé e Isabel de Castro y Castilla, fallecida en 1705. ADB. Burgos. San Román. Libro de defunciones. Sin fechas (1705). 
instituciones, con el telón de fondo del Consulado de Burgos, hubiera, de una forma o de otra, un Tomé en sus asientos.

La longeva existencia de don Pedro Tomé González estuvo llena de inmensas alegrías y de brutales conmociones. Afortunadamente no pudo enterarse -había fallecido en $1764^{16}$ - de las andanzas pecaminosas de su hijo Pedro Celestino, con el cual había mantenido algunos, y muy serios, enfrentamientos, conducta habitual en el clérigo, no sólo con su padre sino con otras muchas personas. Todo el oprobio y la maledicencia le llegaron, en los últimos años de su existencia, a la madre, doña Josefa, cuyo óbito se produce en $1781^{17}$. La narración de los hechos reconstruye una situación espinosa y aberrante que empañó, de forma profunda e hiriente, el honor de los Tomé y salpicó el buen nombre de una dignidad catedralicia, el arcedianato de Burgos, cuyos titulares eran, además y paradójicamente, jueces ordinarios de la diócesis. Los responsables de impartir justicia y dirimir pleitos eran, a su vez, parte abominable en uno de los peores y más negativos ejemplos de trasgresión de la ley eclesiástica del celibato.

En septiembre de 1779, los jueces capitulares don Francisco Ignacio Iñigo Angulo, don Félix José de Haedo y Espina y don Miguel Jerónimo Méndez, «amonestaron a Pedro Celestino Tomé Carrera, arcediano de Burgos, por llevar una vida deshonesta» ${ }^{18}$. El día 8 de mes citado, hicieron comparecer ante su presencia, «congregados en la Sala Capitular de la referida Santa Iglesia», y con la presencia de un notario eclesiástico, es decir, el presbítero secretario del deán y Cabildo, don Francisco Ruiz Cotorro, a Pedro Celestino. Se le acusó abiertamente de mantener relaciones improcedentes y «le previnieron se abstuviese de todo trato y comunicación con cierta Muger procesada y recogida por la Justicia Real». Se le imputaba, sin escrúpulos, «su mala conducta y [practicar una] Vida licenciosa y deshonesta». La realidad aparecía con unos perfiles crudos, porque, «haviéndose esparcido en la vecindad de dho Señor Arzediano un rumor poco decente a la pureza de su Persona y costumbres y menos decoroso a su alto Estado y Dignidad, con motibo del trato que en él se sospechaba con la insinuada Persona y alguna otra de tiempo anterior», se desbarataba la solidez de la limpieza eclesiástica, "así por la obligación que tenía de huir no sólo del Mal sino de la sospecha de él»»19.

${ }^{16}$ ADB. Burgos. San Martín. Libro de difuntos. Legajo $2^{\circ}, 4$ de julio de 1764, folios 305v-306a y Nuestra Señora de Viejarrúa. Libro de difuntos. Legajo $1^{\circ}, 4$ de julio de 1764 , folios $44 v-45 a v$.

${ }^{17}$ ADB. Burgos. Nuestra Señora de Viejarrúa. Libro de difuntos. Legajo $1^{\circ}, 29$ de junio de 1781 , folios $73 \mathrm{av}-74 \mathrm{a}$.

18 Archivo Capitular de la Catedral de Burgos (ACCB). Libro 135, 8 de septiembre de 1779, Burgos, folios 132-133. Véase RodRÍGUEZ SÁNCHEZ (1989), pp. 501-550.

${ }_{19}$ Véase a este respecto M. L. CANDAU CHACón (1990), pp. 185-187.

Hispania Sacra, LXI

124, julio-diciembre 2009, 649-690, ISSN: 0018-215-X 
¿Tales rumores y acusaciones eran realmente ciertos? ${ }^{20}$ No he encontrado nada que permita afirmar la existencia de una campaña organizada de insidias perversas, descalificaciones gratuitas o calumnias sin fundamento contra el arcediano por parte de otras personas. En ningún momento se indica que Pedro Celestino defendiera su honestidad y su virtud y diera pie a una duda razonable en contra de las acusaciones. El arcediano buscó el placer con una mujer de vida muy dudosa. Los jueces capitulares se hacían eco de las habladurías callejeras, del escándalo popular, y del lamentable hecho de encontrarse ante un individuo que ya había caído, al parecer, en la tentación de la carne y acometido el desahogo sexual con otras mujeres.

Las Constituciones Sinodales vigentes en el Arzobispado de Burgos eran, sin duda, conocidas por don Pedro Celestino, aunque él no las practicara. No es sólo que contraviniera el capítulo XIII del Libro III ( «De vita \& honestate clericorum»), según el cual «Contra toda honestidad, del estado eclesiástico es que los clérigos constituydos in sacris acompañen las mugeres por las calles y lugares públicos» 21 , sino que, lo cual es más grave y pernicioso, convertía en papel mojado el Capítulo XVI del dicho Libro («De coabitacione clericorum \& mulierum») en el que se señala abiertamente «Que los clérigos no tengan mancebas ni mugeres sospechosas en sus casas» 22 .

Las oscuras, y reiteradas, actividades sexuales de don Pedro Celestino fueron una fea y sucia mancha en la prístina e inmaculada nómina de los arcedianos de Burgos 23 . Soliviantaba al pueblo y extendía un halo de podredumbre que salpicaba al cuerpo clerical en su conjunto. Sus necedades alimentaron el imaginario social popular que veía en el ama, siempre con connotaciones de probabilidad de relaciones casuales, en la sobrina, alternativa amorosa camuflada, con harta frecuencia, cuando no fruto culpable de las relaciones con el ama, o en algunas de las criadas, amantes clandestinas en el ámbito «familiar» del clero $^{24}$. La respuesta de sus colegas de Cabildo no fue lo contundente que se pudiera esperar. Los jueces capitulares «se veían (...) en la precisión sensible de amonestarle por primera vez y avisarle para que enmendando su porte y conducta procurase en adelante dar el buen exemplo y edificación que está obligado por su Estado Sacerdotal». Únicamente si recaía en tales prácticas, y «en cumplimiento de la obligación de su oficio, procederían a su remedio y castigo por todo rigor de derecho, siempre que llegase a su noticia no haberse aprobechado dho Señor Arcediano de esta corrección y amonestación secreta que, en

\footnotetext{
${ }^{20}$ Cfr. A. VAlencia (1988), pp. 33-45 y M. L. CANDAu Chacón (1990), pp. 185.

${ }^{21}$ Constituciones synodales del Arçobispado de Burgos (CSAB) (1577), pp.129.

${ }^{22}$ CSAB (1577), pp. 130.

${ }^{23}$ A. Blanco DíEZ (1952), pp. 267-298.

${ }^{24}$ L. C. Álvarez Santaló (2000), pp. 112.
} 
obedecimiento de lo prevenido en el Santo Concilio de Trento para la enmienda y corrección de los Clérigos Incontinentes le hacían en la forma dicha» ${ }^{25}$. Nada se dice de la mujer, rea de la Justicia, ni de su futuro, por escaso que éste fuera. Los deslices del clérigo eran en el caso de la hembra flagrantes adulterios.

Esta sesión fiscal se mantuvo en el máximo secreto, dentro de un profundo y sibilino hermetismo, "a fin de excusar se publiquen aquellas manchas y defectos que ofenden a la pureza y vulneran el Decoro deel Estado Eclesiástico con escándalo de los Fieles». Estaban en la obligación de acallar las nocivas secuelas que «el rumor esparcido contra el expresado Señor huviese ocasionado en algunas Personas frágiles». Para reparar, en la medida que fuera posible, el escándalo «le aconsejaron dhos Señores hiciese voluntariamente unos Exercicios espirituales, retirándose por algún tiempo a alguna Comunidad Religiosa, lo que acabando de salir de una enfermedad peligrosa como la que havía padecido sería siempre de mucha edificación y no podía inducir presumpción alguna contra su conducta personal entre los que no se hubiese difundido el expresado rumor $»^{26}$. El proceso concluyó cuando el arcediano se conformó con lo que se le había imputado, señalado e indicado, «ofreciendo no dar el menor motibo de queja y hacer los Exercicios espirituales que se le aconsejaban» ${ }^{27}$.

El silencio cómplice y agradecido de don Pedro Celestino lo dice todo. El que no esgrimiese en su defensa la más mínima respuesta contra sus acusadores, fueran estos laicos o eclesiásticos, otorga veracidad a los rumores, que, a la postre, fueron sencillamente denuncias incuestionables y verídicas de las actividades contrarias al celibato. Don Pedro Celestino no estaba sólo en sus actividades deshonestas. En el Libro 135 del Archivo Capitular de la Catedral de Burgos se anotan varios procesos que, a la luz de lo ocurrido con el arcediano de Burgos, se conocen. ¿Cuántos clérigos mantenían relaciones sexuales con personas de uno u otro género y tenían la suficiente inteligencia y perspicacia como para que nadie se percatara de ello?

En 1782, nos topamos con don Antonio Abadía, racionero y maestro de capilla en la Catedral, a quien los jueces capitulares «le reconvinieron sobre la frecuente entrada que se le notaba en dos ciertas Casas y el trato con las Mujeres Casadas de ellas (cuyos nombres y apellidos constan en testimonio separado que mandaron poner los dhos Señores)». Se denunció el escándalo que tales visitas generaban entre la población y «le amonestaron para que se abstuviese de tratar por sí ni por otro medio así en sus casas como en qualquiera parte con tales Personas ni otras de iguales circunstancias». Como era preceptivo, se le señaló «que lo contrario haciendo se procederá contra él con el mayor rigor,

\footnotetext{
25 CSAB (1577), Libro III, Capítulo II, pp. 133-134.

${ }^{26}$ ACCB. Libro 135, 8 de septiembre de 1779, Burgos, folio 133.

27 ACCB, Ibídem, folio 133.
}

Hispania Sacra, LXI

124, julio-diciembre 2009, 649-690, ISSN: 0018-215-X 
en la inteligencia también de que con testigos de excepción se le puede y podrá probar el exceso, nota y escándalo causado» 28.

En 1785, redescubrimos a don Valentín Calvo, beneficiado en San Martín ${ }^{29}$. Los jueces eclesiásticos «le reconvinieron sobre no haver cumplido lo que el día antes le havían prevenido y el susodho havía ofrecido en razón de hechar de su Casa cierta Criada». Después de haberle amonestado y apercibido de nuevo, se envió al secretario del Cabildo a su vivienda, «mediante asegurar el referido que ya la havia despachado en esa mañana». Don Valentín, atrapado y sin escapatoria posible, entregó la llave de sus estancias y «registrada toda la citada Casa no hallé persona alguna en ella» ${ }^{30}$. El presbítero en cuestión fue calificado como «Capellán Extravagante» por el trato que estaba manteniendo con la criada ${ }^{31}$. En este asunto queda demostrado, de forma fehaciente, el aforismo desarrollado por el imaginario social popular - conocido también por la jerarquía eclesiástica, zarandeada por una marea extenuante de contradicciones lógicas - según el cual «la mucha hacienda en un clérigo escandaliza, la poca lo empuja a conductas indignas de su estado, con probables peores consecuencias $»^{32}$. Empero, no eran únicamente la pobreza uno de los acicates del amancebamiento. Al arcediano Tomé se le podría aplicar el famoso refrán «Hija María, ¿con quién quieres casar?, con el cura, madre, que no amasa y tiene pan» ${ }^{33}$.

En 1786 los jueces también tuvieron que resolver otro espinoso asunto de índole sexual. Don José de la Puente, beneficiado en la parroquia de San Pedro de la Fuente y presbítero capellán en la capilla de la Presentación, incluso en la Catedral, fue reconvenido "sobre la nota y escándalo que, en perjuicio de su Alma y desdoro de su estado, causaba el trato y comunicación con ciertas Personas, Viuda y Soltera, entrando con demasiada frecuencia en su casa y haciéndolo igualmente en la de su habitación y que por lo propio havía sido amonestado por varios sujetos en amistad y algunos Sres de dha Sta Iglesia». El dislate llegó hasta tal punto de osadía y deshonestidad que "se le notaba dho trato aún en sitios sagrados». Viéndose descubierto y acusado, don José confesó sus culpas y manifestó «que en su virtud havia quitado totalmente la comunicación con tales Personas, pues en quatro meses únicamente dos veces havia ido a su Casa, el uno con motibo de dar los Dias de de Sn Jerónimo, y que a la Soltera la tenía advertida que no tenía, ni dentro ni fuera de casa, que tratar

28 ACCB. Libro 135, 17 de junio de 1782, Burgos, folio 123-124.

${ }^{29}$ ACCB. Libro 135, 22 de septiembre de 1785, Burgos, folio 122. Véase F. J. SANZ DE LA HiguerA (2006a), pp. 573-575.

30 CSAB (1577), Libro III, Capítulo II, pp. 133.

${ }^{31}$ ACCB. Libro 135, 22 de septiembre de 1785, Burgos, folio 122.

32 L. C. Álvarez Santaló (2000), pp. 127-128.

33 BeRnal Rodríguez, El hábito no hace al monje. Clero y pueblo en los refranes españoles del Siglo del Oro, Sevilla, 1994, pp. 108. 
con él». Las mujeres con quien «se comunicaba» eran doña Jerónima Arcos, viuda de don José Saiz de Quintanilla, escribano y vecino de la ciudad, y su hija, soltera, doña Mónica ${ }^{34}$.

En 1789, el acusado fue un canónigo catedralicio, clérigo subdiácono, don Tomás de la Peña. Se le imputó «trato y comunicación» con una mujer casada, doña Manuela Bernal, cónyuge de don Antonio (Sainz) de Viniegra, miembro de la burguesía mercantil burgalesa ${ }^{35}$.

Dos anécdotas para finalizar con las andanzas del arcediano de Burgos Tomé Carrera. Su sucesor en el cargo capitular fue uno de los jueces que le encausaron en 1779, don Francisco Ignacio Iñigo de Angulo, magistral y abad de Cervatos. El óbito de Tomé se produjo en abril de 1783 sin haber redactado ni rubricado sus últimas voluntades ${ }^{36}$. El Rey, «...por haber fallecido en uno de los meses reservados» $\mathrm{y}$ «atendiendo al mérito y buenas prendas de Dn Francisco», ejerció su potestad de presentar al Cabildo de Burgos para dicha titularidad al mencionado Iñigo de Angulo. Una Cédula Real, dirigida al arzobispo Arellano, efectuó dicho trámite ${ }^{37}$. La posesión definitiva se produjo a finales de agosto ${ }^{38}$. Don Francisco era clérigo de órdenes menores, profesor de Sagrada Teología y colegial en el Colegio Mayor de San Ildefonso de la Universidad de Alcalá. Primogénito de un vecino muy sobresaliente y prestigioso, don Bernardo Iñigo de Angulo, regidor perpetuo, a mediados de 1751 lo encontramos como «estudiante de gramática y filosofía» ${ }^{39}$. En 1770 ganó por oposición ${ }^{40}$ la prebenda de Magistral, tras la muerte de don Diego Escalona ${ }^{41}$. Esta ocupación, aneja a la abadía de Cervatos, hubo de abandonarla al ser ascendido al arcedianato de Burgos ${ }^{42}$. Desde 1771 actuó como Capellán mayor de la capilla de la Purificación. Trasladado el deán Pérez Arenillas al obispado de Gerona, por nombramiento de Carlos IV -3 de julio de 1789 a 27 de abril de 1796-, también a él, a don Francisco Ignacio, le llegó el turno de acceder a la máxima autoridad catedralicia burgalesa. Pidió posesión del deanato el 17 de julio de 1797, se posesionó el 27 de diciembre y vacó el 15 de septiembre de 1798 al ser promocionado al obispado de Osma. No No llegó a ejercer su cargo pues, aunque tomó posesión el 23 de noviembre, falleció en Madrid el 8 de enero de $1799^{43}$.

\footnotetext{
${ }^{34}$ ACCB. Libro 135, 8 de noviembre de 1786, Burgos, folios 125-126.

35 ACCB. Libro 135, 10 de enero de 1789, Burgos, folio 127.

${ }^{36}$ ACCB. Actas Capitulares. LR 117. Cabildo del 4 de febrero de 1784, folios 428-429.

${ }^{37}$ ACCB. Libro 132, 24 de agosto de 1783, folios 499-500.

38 ACCB. Libro 132, 30 de agosto de 1783, Burgos, folio 502.

${ }^{39}$ ADPB. Catastro. Libro 344, folios 473-479.

40 ACCB. Libro 132, 15 de abril de 1770, Burgos, folios 499-501, 506, 524-533 y 564.

${ }^{41}$ Sobre oposiciones, véase A. Morgado García (2000), pp. 82.

42 ACCB. Actas Capitulares. LR 116. 6 de junio de 1781, folio 238.

${ }^{43}$ A. Blanco Dítz (1945), p. 548.
} 
Don Francisco Iñigo sabía que «las posibilidades de ascenso aumentaban con los estudios jurídicos, el doctorado, la carrera universitaria y la edad elevada, reemplazándose los privilegios de la herencia por los méritos personales» ${ }^{44}$. Era un estudioso, una persona ilustrada que dedicó su existencia (1735-1799) a escalar los peldaños de la carrera eclesiástica y a la lectura, la investigación y la redacción de anotaciones sobre la historia de Burgos. Agustín Ceán Bermúdez le mostró públicamente su agradecimiento en múltiples ocasiones ${ }^{45}$.

El contraste entre el juez fiscalizador, don Francisco Ignacio, y el acusado de deshonestidad y de prácticas ilícitas y aberrantes, don Pedro Celestino, trae a colación, como telón de fondo, el talante humano, la idiosincrasia y la significación socio-económica de las dos familias en las cuales se integran. A la postre, se trata de dos fórmulas diametralmente diferentes de vida, dos estrategias substancialmente divergentes.

Una, la de los Iñigo, estaba lastrada por el devenir y los parámetros cada vez más obsoletos del Antiguo Régimen, si bien mostraban algunos perfiles progresistas y puristas que les distancian de los más retrógrados y oscurantistas. Los Iñigo de Angulo eran borbónicos hasta la médula pero se encontraban atrapados por su propia historia y trayectoria. Tienen nombre y, sin embargo, disponen de pocos caudales.

Los Tomé, eran unos nuevos ricos, hechos a sí mismos en las duras batallas que se suceden durante el Setecientos para implantar en Castilla la administración borbónica y las prácticas capitalistas de la nueva economía. No tenían mucha historia pero su arduo trabajo, sus estrategias empresariales arriesgadas y exitosas y sus contactos e influencias les permitieron escalar hasta posiciones muy encumbradas. Los Tomé eran, junto con los Sánchez de Valencia, algunos de los dedos más importantes de la mano Real en la ciudad de Burgos.

Los Iñigo de Angulo aportan el sabor rancio y recio de la nobleza más encumbrada, aristocrática y vetusta de la ciudad de Burgos. Eran hidalgos de raigambre notoria, con casa principal en su lugar de origen y un rango nobiliar sólido e indiscutible. Venidos a menos en el Setecientos, sus raíces y prestigio se rastrean en los siglos más florecientes de la «caput castellae», especialmente en el lustroso siglo XVI ${ }^{46}$.

\footnotetext{
${ }^{44}$ A. Morgado García (2000), pp.87.

45 Sobre don Francisco Iñigo Angulo véase R. N. PAYo Hernanz, Arte y sociedad en Burgos en la segunda mitad del siglo XVIII, Burgos, 2003, pp. 19-20 y A. BLANCO DíEZ (1945), pp. 548.

46 A. C. IBÁÑEZ PÉreZ, Arquitectura civil del siglo XVI en Burgos, Burgos, 1977 y Burgos y los burgaleses en el siglo XVI, Burgos, 1990. C. CAMARERo Bullón, Historia de Burgos. Siglo XVIII, Historia Moderna, I, Burgos, 1991, pp. 205-206 y R. N. Payo Hernanz (2003): Op. Cit, pp. 77, 92, 95-98, 114-115 y 132 .
} 
A mediados del XVIII tenían unos niveles de renta y de fortuna modestos, serios problemas de habitabilidad en la vivienda que ocupaban ${ }^{47}$ y no disponían de carruaje entre sus pertrechos ${ }^{48}$. En su inventario post-mortem se anotan pertrechos y propiedades libres por valor de 400.000 reales, cantidad no excesivamente voluminosa pero sí substanciosa e importante entre la aristocracia burgalesa ${ }^{49}$. Si los cálculos no me fallan, su útil anual no sobrepasaba, en el momento en que se efectúa el Catastro de Ensenada, los 20.000 reales, fruto de sus percepciones como regidor perpetuo $-14.4 \%$-50, de los intereses de los juros que poseían -3.7\%-, de las rentas devengadas por bienes inmuebles poseídos en la ciudad de Burgos $-10.2 \%{ }^{51}$, de las procedentes de su patrimonio en diversas localidades de la provincia $-17.5 \%-\mathrm{y}$, especialmente, de sus volátiles y temporales salarios y dietas como juez subdelegado para la Única Contribución, quehacer profesional en el que don Bernardo obtenía el 54.2\% de sus ingre$\operatorname{sos}^{52}$. Su más notable aportación al desarrollo social de Burgos fue la autoría del informe para la erección del Hospicio, impreso por José de Navas en 1767, con el título «Puntual noticia (...) del establecimiento de la Real Casa Hospicio de la Ciudad de Burgos» ${ }^{53}$. Codo con codo con el denostado y maltratado arzobispo Rodríguez de Arellano, protagonizó algunas de las empresas más ilustradas y progresistas de su época, tanto desde el punto de vista asistencial como estético y vanguardista ${ }^{54}$.

Los Tomé eran unos «parvenus», enriquecidos tenderos convertidos en acaudalados ganaderos de ovejas merinas y asentistas de la Santa Cruzada. Su origen navarro remoto y su procedencia más cercana, enraizada en Melgar de

${ }^{47}$ ADPB. Catastro. Burgos. Libro 344, folios 473-479.

${ }^{48}$ F. J. SANZ DE LA Higuera, «Una estancia doméstica que se mueve. Entre las calles y las casas de Burgos a mediados del XVIII»·, Cuadernos de Investigación Histórica, 21 (2004), Madrid, pp. 469506.

${ }^{49}$ AHPB. PN. Ángel Arnaiz. Legajo 7173 (22 de abril de 1776), folios 628-657.

${ }^{50}$ ADPB. Catastro. Burgos. Libro 344, folios 473-479. Don Bernardo, quizá por excentricidad, por un prurito de honradez extrema o por llevar la contraria, y dejar en evidencia, a sus compadres del Concejo, declaró que percibía como «Rexidor perpetuo con voz y voto en el Ayuntamiento 4.000 mrds [117 $1 / 2$ reales] con la previsión de asistir, al menos, a 48 ayuntamientos en el año; Por tomar posesión de dho oficio me pagan de media Annata $24.262 \mathrm{mrds}$, por el Real título 120 reales y de propinas y Gastos de escritorio 2.806 reales al año». les.

${ }^{51}$ Era propietario de 6 edificios en la ciudad, por cuyos alquileres percibía anualmente 2.063 rea-

${ }^{52}$ La transparencia demostrada en señalar sus ingresos municipales quedó en agua de borrajas en lo tocante a declarar sus actividades como juez subdelegado para la Única Contribución, en la que al año le correspondía una cantidad cercana a los 11.000 reales, emolumentos que se olvidó de declarar.

53 C. Camarero Bullón (1991): Op. Cit., pp. 206.

${ }^{54}$ R. J. Payo Hernanz (2003): OP. Cit., pp. 77, 92-98, 114-115 y 132 y L. S. Iglesias Rouco, Arquitectura y urbanismo de Burgos bajo el Reformismo Ilustrado (1747-1813), Burgos, 1978, pp. 105106 у 68-69.

Hispania Sacra, LXI

124, julio-diciembre 2009, 649-690, ISSN: 0018-215-X 
Fernamental (Burgos), nos presenta a una saga de discutidos hidalgos con notable influencia en la economía burgalesa aunque, en la práctica, eran unos recién llegados. Emparentados por matrimonio con los Carrera, familia oriunda de Segovia, adquirieron una pátina de respetabilidad y solvencia indiscutible, merced a su notable capacidad para multiplicar el beneficio de sus inversiones y la calidad de sus contactos económicos y políticos. Los Tomé se encuadran en una incipiente y renovada clase burguesa, implicada en la gestión del Consulado de Burgos y en el fomento del comercio y la industria. El Inventario post Mortem, elaborado en 1764, acumulaba propiedades por un valor cercano al millón y medio de reales ${ }^{55}$. En 1724, al enviudar de doña Isabel de Castro, su primera esposa, su caudal patrimonial ascendía a aproximadamente 340.000 reales $^{56}$. La gestión de la Santa Cruzada, el manejo de un lavadero y de una cabaña lanar trashumante y sus meditadas y siempre acertadas inversiones productivas le catapultaron desde su oscura actividad como mercader por menor hasta su conversión en el segundo contribuyente a la Hacienda pública de la ciudad ${ }^{57}$.

Su nivel de ingresos, situado entre los 80.000 reales según los peritos catastrales y los 53.000 reales según sus propias evaluaciones, nos muestra, sea en uno u otro caso, unas sólidas y diversificadas percepciones. Don Pedro Tomé evaluaba que la Santa Cruzada y la administración de los intereses de varios nobles le rentaban 7.400 reales (14.1\% de sus ingresos). Los peritos catastrales lo elevaban hasta los 14.000 reales $(17.6 \%)$. El manejo de las lanas generaba, en palabras de don Pedro, 12.500 reales (23.7 \%). La Hacienda pública lo evaluaba en 32.640 reales $(41.1 \%)$. Las rentas de sus propiedades en Burgos -en ello estaban ambos de acuerdo- 1.349 reales (entre el 2.5 y el $1.7 \%$ de sus percepciones, respectivamente). Sus propiedades e intereses en varias localidades de la provincia le hacían llegar anualmente un montante ligeramente superior a los 31.000 reales, es decir, el $59.7 \%$ de sus ingresos según la contabilidad de los Tomé o el $39.6 \%$ según las evaluaciones de los expertos de Hacienda ${ }^{58}$.

La honorabilidad ilustrada, discreta y modesta de los Iñigo de Angulo chocaba, de manera manifiesta, con la rutilante y enfebrecida fortuna de los Tomé, alguno de cuyos componentes acabaron sus días perseguidos por la justicia, fuera laica -Juan Manuel- o eclesiástica -Pedro Celestino.

\footnotetext{
55 AHPB. JM. Juan Antonio Fernández Guilarte. Legajo 977 (14 de julio de 1764, folios 21-127.

56 AHPB. PN. Martín de Robredo. Legajo 6964 (14 de enero de 1724), folios 340-353.

57 Archivo Municipal de Burgos (AMB). Carpeta 2-8-4 (5 de junio de 1748), folio 9.

58 ADPB. Catastro. Burgos. Libro 347, folios 92-96.
} 
El NOMBRAMIENTO PONTIFICIO EN FAVOR DE PEDRo CELESTINO PARA ARCEDIANO DE BURGOS

La llegada al arcedianato de Burgos de este último estuvo rodeada de un cúmulo de circunstancias que permiten hablar abiertamente de tráfico de influencias y de un funcionamiento enmarañado de las redes clientelares ${ }^{59}$. «Y fuere ociosa y regalada, o esforzada y trabajosa -señala el profesor Morgado García-, el tener al menos la posibilidad de disfrutarla era algo sumamente disputado, si tenemos en cuenta las numerosas fuerzas que actuaban cada vez que una prebenda quedaba vacante» 60 .

La secuencia de los hechos, con don Pedro Celestino en Roma, es como sigue. El 4 de mayo de 1751, Benedicto XIV confiere, en el Vaticano, a Pedro Celestino la dignidad de arcediano titular de la Iglesia de Burgos a través de la «Nobilitas generis vitae» ${ }^{61}$. Ese mismo día, una bula del citado Papa, la «Hodie dilecto filio», dirigida a José Simoneti y a don Felipe Carrera Castro y Castilla, canónigo, anuncia paralelamente la provisión del arcedianato ${ }^{62}$. El 6 de mayo se recibe una carta de don Pedro Celestino, desde Roma, en la que anuncia al Cabildo de Burgos que Benedicto XIV le ha concedido la dignidad en juego, tras la resignación a su favor de don Manuel Arnaiz ${ }^{63}$. El 18 de mayo son trasladadas oficialmente al Cabildo las dos bulas originales ${ }^{64}$. El 11 de junio, Benedicto XIV confiere, desde su residencia veraniega de Castelgandolfo, a don Manuel Real Varona el canonicato vacante por la muerte de Hoyo Santamaría ${ }^{65}$. Don Pedro Celestino vio así como se esfumaban la mitad de sus hipotéticos ingresos capitulares y cómo únicamente sería merecedor de una prebenda como arcediano. El día 19 de julio, don Pedro Celestino, subdiácono, aún en Roma, rubrica un poder en el que señala a don Diego Zamora Huidobro, capiscol y canónigo, y a don Felipe Carrera Castro, su tío, canónigo, para que en su nombre tomen posesión del arcedianato de Burgos, dignidad que le ha concedido el Papa por permuta con Manuel Arnaiz, canónigo ${ }^{66}$.

Disponemos de 5 cartas remitidas por don Pedro Tomé González a su hijo Pedro Celestino, datadas entre el 28 de mayo y el 5 de julio de $1752^{67}$. Burgos y

${ }^{59}$ Véase J. M. Imízcoz BeunZa (1996), (2001a), (2001b) y (2002).

${ }^{60}$ A. Morgado García (2000), pp. 79 y 83.

${ }^{61}$ ACCB. Libro 111, 4 de mayo de 1751, folios 651-652.

62 ACCB. Libro 111, 4 de mayo de 1751, folio 652.

${ }^{63}$ ACCB. Libro 108, 6 de mayo de 1751, folio 97.

${ }^{64}$ ACCB. Libro 111, 18 de mayo de 1751, folios 651-652.

${ }^{65}$ ACCB. Libro 116, 11 de junio de 1751, folio 54 y Libro 111, folios 661-662.

${ }^{66}$ ACCB. Libro 111, 9 de julio de 1751, folios 644-645.

${ }^{67}$ AHPB. JM. Juan Antonio Fernández Guilarte. Legajo 977 (14 de julio de 1764), folios 453 y 462-464. Sobre correspondencia, véase, por ejemplo, J. M. Imízcoz BeunZa (2002), J. Garmendía 
Roma se convirtieron en lugares de origen y destino de un cruzado duelo dialéctico entre un padre y un hijo cuyas relaciones tenían, al parecer, bastante de instrumentales y técnicas pero que adolecían de calor humano y posiblemente de afecto ${ }^{68}$. Don Pedro Celestino las tenía en su poder y fueron utilizadas como arma arrojadiza por el clérigo contra sus padres años después. De ellas se desprende que fue sometido a lo que él creía un auténtico atropello, que le devoró las entrañas, le mantuvo forzosamente fuera de Burgos y convertido en un mero sirviente de un cardenal al que quizá odiara y, lo que es más grave, despreciaba abiertamente.

En la primera misiva, del 28 de mayo ${ }^{69}$, don Pedro corresponde a su hijo clérigo por la que éste le había mandado el día 6 , anunciando «la tan apreciable noticia de Haver sido Dios servido aias Logrado la fortuna de Hallarse Arcediano desta Ciudad, dignidad de la Sta Iglesia, que todo se debe a su Eminencia, tu Amo y mi Dueño». Don Pedro le pide a Celestino «que con la mayor veneración me pondrás dándole millones de grazias asta que en primer Correo lo Haga yo, pues sólo la piedad y grandeza de su Eminencia Lo podía Haver Echo». Le insistió reiteradamente que se dejara "guiar por lo que Nro Emmo Sor te mandare» y le puso los puntos sobre las íes. «No discurras Venirte a España hasta Lograr una Renta dezentte y Correspondiente, pues oy es fácil, manteniéndote ay, y estando el Emmo Sr Cardenal Daturio en favorecerte Con Canonicato, Razión entera o Rentas simples, pues Conozerán, y Con rrazón, que para una dignidad Como te an dado y para su dezencia es menester Renta correspondiente y más haviendo pensionado dha Dignidad y dado tu Arziprestazgo».

Don Pedro era conocedor de la impaciencia y los modos agrios de su hijo. La carta del 28 de mayo deja traslucir el talante emprendedor y arriesgado del padre, don Pedro Tomé González, y el espíritu más timorato y retraído de Pedro Celestino, quizá sobrecogido por las pretensiones, a veces tiránicas y manipuladoras, del progenitor. «Con que espero -escribe don Pedro- (...) Lo Logres, por lo que es menester mantenerte ay, que se Haze más en dos meses que en un año

Arruebarrena (1990), Antón Pelayo (2005), Bouza Álvarez (2005) y Martín Baños (2005) -el Anejo IV de los Cuadernos de Historia Moderna (2005) «Cultura epistolar en la alta Edad Moderna. Usos de la carta y de la correspondencia entre el manuscrito y el impreso», coordinado por el profesor BouzA, es un excelente referente a tener siempre en cuenta de manera imprescindible-.

${ }^{68}$ De entre la bibliografía disponible sobre las relaciones entre padres e hijos descuellan, en especial y sin un ánimo exhaustivo, M. Daumas (1990), J. Delumeau y D. Roche (1990), A. Rodríguez Sánchez (1990), L. Villafuertes García (1991), M. Ortega López (2000) y J. Hernández Franco (2004). Es muy interesante la lectura de D. ALEXANDRE-BIDón, «Images du père de famille au Moyen Âge» y D. LETT, «Pères modèles, pères souverains, pères réels», Cahiers de recherches medievales, 4 (1997), «Éter père à la fin du Moyen Âge».

${ }^{69}$ AHPB. JM. Juan Antonio Fernández Guilarte. Legajo 977 (14 de julio de 1764), folio 461. 
desde acá, y de qualquiera Cosa infórmate bien y avísame antes de Expedir bula ninguna, que una vez echa la gracia ay lugar para todo, teniendo un poco de paciencia y pidiéndoselo a Dios y a su Ssma Madre». Sin duda, don Pedro tenía sobrados motivos, por el proceder de Pedro Celestino con anterioridad, para insistirle de forma tan contundente sobre qué hacer y cómo hacerlo. Estaba invirtiendo fuertes sumas de dinero y recurriendo a múltiples fórmulas de presión e influencia entre sus amistades y protectores en la Corte y en la Iglesia para conseguir que su hijo medrara en los intrincados vericuetos de la carrera eclesiástica. No se podía permitir el lujo de ver como los malos modos y la falta de tacto lo arruinaban todo. En la misma carta le anuncia también que «por lo que mira al Beneficio simple de Villada que se te a Conferido estoy tomando ynforme por menor de que te avisaré para que siendo corriente expidas la Bula, la que Desempeñaré prontamente, Como lo ejecutaré Con la de dho Arcedianato, que oy Remito Letras a don Francisco del Arco, Vezino de Madrid, para que Luego al instante acuda a Dn Carlos María Marrazi, que tamvién es un Amigo, para que satisfaga su importe y me las remita prontamente». Y remata la faena, hurgando de nuevo en otra herida abierta entre ellos, al hacer mención de la necesidad de informarse bien sobre el «Beneficio simple de Murcia» y al obligar a Pedro Celestino a aparecer en escena como un mero títere en manos del padre. La siguiente frase es categórica: «Al Sor Dn Miguel Antonio de la Gándara darás de mi parte miles de gracias por su garbo y favor, de lo que quedo mui reconocido. $Y$ en primer Correo tamvién le escribiré, y de qualquiera Cosa guiaté tamvién por lo que ese Caballero te dijere».

En la segunda carta, del 2 de junio ${ }^{70}$, reitera «el gran gusto que todos en esta tu Casa tubimos Con la noticia que me diste de Haver Logrado el Arcedianato». También fue celebrado por el Cabildo catedralicio «así Como todo lo principal desta ziudad an benido a Casa gustosos a dar la Enora buena». Le señala, de nuevo, que ha escrito al Cardenal, «tu amo y mi Dueño, dándole millones de gracias, pues no esperava yo menos de su grandeza y Piedad». Hasta ahí el festejo pero después lo amargo. Pues «pensionada dha Prevenda [el arcedianato] y no quedarte Renta Correspondiente para tu dezenzia [es preciso] se digne aplicarte algunas más para que Vengas como su echura, lo que no dudo ejecutará, y asta tanto te Manttendrás en servicio de su Eminencia, que es el mayor Logro que podemos desear (...) y para que Vengas con el acomodo dho es preziso te Ingenies a lograr algunas Rtas simples por sino ay Vacantes de Algún Canonicato que con chas Simples podrá llegar el Caso de Alguna permuta por que Como el Arcedianato no tiene Voto, y es el titular, queda Manco». Es preciso rentabilizar el viaje a Roma a toda costa y repartir abrazos por doquier. «... y puedas estar con el padre Colindres y Sor Gándara a quien de mi partte y toda

${ }^{70}$ AHPB. JM. Juan Antonio Fernández Guilarte. Legajo 977 (14 de julio de 1764), folio 462.

Hispania Sacra, LXI

124, julio-diciembre 2009, 649-690, ISSN: 0018-215-X 
la familia darás millones de grazias y pórtate con todo Juicio, Cortesía y humildad porque ya eres otro hombre».

La carencia de un canonicato era lacerante y don Pedro no tenía escrúpulos en recriminar por esto constantemente al clérigo. Insiste, Celestino, insiste, le dice el padre al hijo, «y esto se hará con toda atención y Cortesía visitando a menudo a dho Sor porque no hazes nada Con grandeza sin Renta». Entre líneas se advierte que Pedro Celestino no estaba muy cómodo en Roma y menos a las órdenes del Cardenal al que servía. De la misma forma que en la carta anterior -en las que se acababa con un «tu Madre, Hermanos y toda la familia te Envían mil Cariños»-en esta del 2 de junio se remata con un «tu Madre y Hermanos te Envían afectuosas memorias y todos pedimos Dios te Guarde muchos años». Se echa de menos el aprecio del padre. A lo sumo, aparece un protocolario y frío «Tu Padre que mucho te estima».

En la tercera «Valija», del día 8 de junio ${ }^{71}$, la situación no ha cambiado, «Y respecto de que no ay Canonicato ni Razión Vaco en esta Sta Iglesia [es preciso] detenerte ay para ir Cojiendo Todas las Rtas simples que pudieres, pues Con ellas o parte se podrá hazer acá alguna permuta de un Canonicato para que tengas Voto Con la dignidad porque sin él no tendrás Manejo. Y así estate quieto ay pues tienes tus Socorros seguros, hasta que me des aviso de haverlos logrado y Venir en forma».

La cuarta carta, del 23 de junio de $1751^{72}$, es, a mi modesto entender, un crudo ejercicio de descalificación y reproche hacia el hijo ausente. A Pedro Celestino sólo le cabría, en la lejanía de la Roma en la que se hallaba, un hondo sentimiento de pusilanimidad. En primer lugar, le recriminaba que el poder que mandó el 26 de mayo «no sirve, lo primero por no benir en forma y lo segundo benir a favor de dn Juan Barrón y mío que ni uno ni otro no podemos tomar la posesión». La certera eficacia de don Pedro chocaba diametralmente con la chapucería grosera e irresponsable del clérigo. Don Pedro le indica que envíe otro poder y esta vez «a favor del Doctor dn Phelipe Carrera, canónigo de esta Sta Iglesia, y del Doctor dn Diego de Zamora Huidobro, Capiscol en ella, y que dho poder Venga en toda forma para que no aya el más mínimo Reparo». Es muy probable que alguna irónica sonrisa o incluso alguna sonora carcajada se viera o escuchara entre los más reacios a admitir a los Tomé entre sus filas. Don Pedro, muy proclive al enfado, echaría chispas. Para colmo de males, Pedro Celestino remitió una bula para el Arcedianato a Madrid «Contra dn Pedro González Carrera, Cuia equivocación nos a echo andar alrededor, y aora se está reconociendo la Bulla en Madrid para ver si trae el mismo nombre y apellido y

\footnotetext{
${ }^{71}$ AHPB. JM. Juan Antonio Fernández Guilarte. Legajo 977 (14 de julio de 1764), folio 464.

${ }^{72}$ AHPB. JM. Juan Antonio Fernández Guilarte. Legajo 977 (14 de julio de 1764), folio 463.
} 
podrá aver algún reparo. Pero creeré que en ella se aya puesto dn Pedro Thomé Carrera que fuera un descuido Grande».

El plato fuerte de esta carta son los párrafos en que don Pedro Tomé comenta lo que le está costando el viaje a Roma y sus intenciones de convertir a su hijo en canónigo y dignidad de la Catedral de Burgos. No tiene pelos en la lengua cuando le recuerda al clérigo lo siguiente: «No sé cómo ajustarás la quenta de dha Vulla pues Importa 31.911 rrs y 6 mrs, Inclusos 10 rrs del Portte, Cuia cantidad está entregada a dn Francisco del Arco para que viniendo bien la recoja y me remita dha Vulla, y no me dizes la pensión que se a cargado sobre dho Arcedianato que creo será grande, y dizes que con tus rentas se sanearán luego sus Cortos. Te prebengo que dho Arcedianato no bale residido más que 600 Ducados Vellón que Valen 6600 rrs que revajada dha Pensión no tte quedará para Comer sino logras algunas rentas más para la Dezenzia de tu Persona y así es preziso te unjenies manteniéndote ay y suplicando a su Eminencia te favorezca con algunas rentas simples, como asimismo al Rmo Padre Colindres y otros de quienes puedas valerte, mantiéndote como llevo dho en esta Cortte, como te a mandado tu amo, $Y$ yo te mando lo mismo».

Don Pedro ha investigado por su cuenta sobre «el Veneficio simple que dizes te abian dado en la Villa de Villada por muerte de dn Luis Rodríguez, Vecino de León, que balía 300 Ducados en cada un año». La realidad es que «su balor es de 48 fanegas de pan por mitad que Valen 440 rrs sin otra Cosa, con que se Ubieras expedido la bula quedábamos luzidos. Y así te prebengo mires lo que azes porque ay noticia que a coger dinero y en ganar es preciso abrir los ojos».

Y le pone la puntilla con otra demoledora reflexión: «también te prebengo que oy con tu Arcedianatto puede llegar la ocasión de que puedas lograr alguna Dignidad de las Rurales desta Sta Iglesia, Como son la de Valpuesta o Salas, pero ya el Rey las Probee Como ha hecho con la Abadía de Castro, con que no ay que Pensar en ello, sí sólo, Como llevo dho, en rentas simples el tpo que pueden lograr o si baca aquí algún Canonicato, que si llega el caso te lo avisaré prontamente».

En la carta del 5 de julio de 1752 don Pedro Tomé González ironiza con frases del tenor siguiente: "Sin embargo de que mis Documentos y Cartas no te sirven de govierno ni haces caso de ellas, y no tenía ánimo de escribirte, sirve ésta de acompañar las dimisorias y para que ai tte ordenes de evanjelio y missa con qualquiera Sor Arpo ó Obispo, para que con esso no ttengamos que vesar las manos aquí a ninguno». Sacudiendo de nuevo la fibra sensible de lo económico, concluye diciendo que «escrivo a su Ema este correo y las gracias de lo mucho que nos a favorecido y Conseguido que ttengas alguna más renta, avisarás para darte la orden de venirte, con que así procura coger lo que puedas, porque sino no ttienes que comer». Al margen aparece un breve texto, a

Hispania Sacra, LXI

124, julio-diciembre 2009, 649-690, ISSN: 0018-215-X 
modo de post-data, en el que el padre remueve su dedo acusador en la herida hiriente de la insatisfacción y la impotencia: "Puede ser que la caridad de $\mathrm{Su}$ $E^{a}{ }^{a}$, tu amo, aplique algún Veneficio Simple si a sí as echo para Merecerlo»73.

Don Pedro Celestino retornó de Roma sin el canonicato, prebenda que jamás consiguió. En Burgos le esperaba una factura de 111.546 1⁄2 reales de vellón, cantidad invertida por sus padres en sus estudios y su estancia en Roma, convenientemente anotada hasta el último de los «Diferentes papeles y recados de su Justificación, que todo corre desde el folio Ciento y ocho asta el Ciento y Cinquenta, amvos Inclusive de la Citada Segunda Pieza» ${ }^{74}$.

No es de extrañar que entre los hermanos Tomé, hijos de don Pedro y doña Josefa, existieran fuertes disensiones e incluso agrios enfrentamientos, que finalmente también alcanzaron a la madre, una vez muerto el progenitor. Las inversiones ante-mortem de don Pedro en su hijo entonces predilecto, su mano derecha y lugarteniente, alcanzaron el $44.2 \%$ (191.7256 reales) de las inversiones de don Pedro en sus vástagos. En segundo término aparece el mencionado Pedro Celestino, con un $25.7 \%$ (111.546 1/2 reales). En Fernando recayeron el $18.7 \%$ (81.336 1/2 reales) y, finalmente, en Antonio un $11.4 \%$ (49.332 1/2 reales).

En marzo de 1765, al hilo de las «Quentas y particiones» de los bienes de su padre, don Pedro Celestino presenta una relación de «Reparos (...) que pongo a las Quenta que de gastos de mis estudios y ottras cosas pareze que se ha formado por mi Sra Madre»75. Asume como legítimos 2.376 reales «que tubo de Coste la Bulla de pensión sobre el beneficio de Almarza», 1.188 1/2 reales «de la Bulla deel Arziprestazgo de Melgar», 1.000 reales de los 4.666 reales «de diferentes partidas por mi rezivida en Barcelona», 31.911 reales de las bulas del arcedianato y $31.577 \mathrm{l} / 2$ reales de letras giradas a su favor -hemos de suponer que para su mantenimiento-. La suma de todo ello supone 68.053 reales, es decir, un $61 \%$ de lo que sus padres le imputan en desembolsos para su formación y acceso a la dignidad catedralicia. Rechazó, porque «no se documenta y por lo mismo no debe ser admisible», una partida de 3.000 reales «que se dicen entregados por mi Sra madre al ttiempo que marché a Roma», 3.666 reales de la citada «rezivida en Barcelona», 4.015 reales de una letra girada a Roma con fecha de 2 de enero de 1751 -de la que afirma "no se documenta en manera alguna pues falta mi libranza que precisamente hubiera dado de dha cantidad, como hize con las demás que en aquella Corte se m enttregaron»-, 14.833 1/2 reales «por carezer de documento que acredite haverseme entregado ni servido en mi utilidad (...) por lo que no pareze Justo se abone» y 17.9997 reales «que

\footnotetext{
${ }^{73}$ AHPB. JM. Juan Antonio Fernández Guilarte. Legajo 977 (14 de julio de 1764), folio 453.

${ }^{74}$ AHPB. JM. Juan Antonio Fernández Guilarte. Legajo 977 (14 de julio de 1764), folios 108-150 y 455-506 (inventario post-mortem y «Quentas y Particiones»).

${ }^{75}$ AHPB. JM. Juan Antonio Fernández Guilarte. Legajo 977 (14 de julio de 1764), folios 457-460.
} 
se dicen entregados para pagar la pensión deel Arcedianatto, en Ajuares y ottras Cosas, Carecen de formal requisito que compruebe dha entrega, por lo que no deve haver lugar a el abono» ${ }^{76}$. No admitía, por tanto, un $39 \%$ de los gastos anotados por su padre y después reutilizados por su madre.

Además, reclamaba se le abonaran 5.280 reales, «los mismos que en el discurso de 12 años contados desde el de 1742 asta el de 53 ynclusive, y a razón de 4.000 reales en cada uno, me produjo el Beneficio de Almarza y cobró dho Sor dn Pedro Thomé, mi Padre» y 21.780 reales «que en el discurso de 11 años, conttados desde el de 1743 hastta el de 53 ynclusibe, y a razón en cada uno de $180 \mathrm{du}$ cados,(...) me produjo el Beneficio simple de la villa de Melgar que en igual forma percivió dho mi Padre». Asimismo, exigía se le rebajasen «enteramente de dha Quenta el gasto que en Roma hize o pude hazer desde el mes de Junio de 1751 hasta el de Julio de 52, porque con anterioridad a este tiempo tube mi Prevenda de Arcediano y haviendo por lo mismo escrito a dho mi Padre quería restituirme a esta Ciudad, me lo impidió por repetidas Carttas». Su exacerbada irritación contra padres y hermanos llegó hasta el punto de reclamar a los contadores y las autoridades que por «haver aprovechado en mis estudios como lo evidencia el echo mismo de haver conseguido el grado con que me hallo de Doctor ${ }^{77}$ y ser la Dignidad que obttengo la segunda silla desta Sta Iglesia 78 y por lo mismo mui honrrosa a la Casa, deverán o no responder mis lexitimas por el Costte de Bullas y demás gastos, vien que en qualquier evento pareze es correspondiente la revaja de el gasto regular en quanto a la manutención, calzado, Medicina, etc, por quanto está obligado a ello todo Padre, según su hazienda y Calidad»79.

Los conflictos en los hogares y familias que disponían de patrimonio eran un fenómeno habitual, lejano del habido entre quienes no tenían mucho que repartir. Así, por ejemplo, Santiago Mazuelas, un maestro sastre de escasos recursos, señaló en sus últimas voluntades, que a su hijo «no se le quente en quenta de herencia cosa alguna por razón de los gastos hechos en sus estudios, y en caso nezesario en el importe de ellos le mejoro, en quento coja, en el tercio de mis bienes» ${ }^{80}$.

${ }^{76}$ AHPB. JM. Juan Antonio Fernández Guilarte. Legajo 977 (14 de julio de 1764), folio458v.

77 Lamentablemente al día de hoy no he conseguido saber en qué Universidad se doctoró, descartadas las de Salamanca y Valladolid, desde cuyos Archivos Históricos me comunican amablemente doña Victoria Barcina Cuevas y doña Ángeles Moreno, respectivamente, que no se dispone de ninguna información sobre sus estudios.

${ }^{78}$ En efecto, el arcedianato de Burgos era la cabeza visible del coro de su nombre, lo que daba un notable lustre a su poseedor, que rivalizaba con el deán, comandante del otro coro. Véase F. LANGUE (2005) y M. Moreno Alonso (2000): Op. Cit., pp. 39, 57 y 166-169.

${ }^{79}$ AHPB. JM. Juan Antonio Fernández Guilarte. Legajo 977 (14 de julio de 1764), folio 459v.

${ }^{80}$ AHPB. Protocolos Notariales (PN). Ángel Arnaiz. Legajo n7166 (14 de enero de 1763), folio 316. Por lo que se desprende de la redacción del testamento, se trata de un matrimonio feliz, gozoso y bien avenido en el que durante su vida conyugal «se an aumentado los vienes de mi Casa más de una mitad de todos los que al presente me allo».

Hispania Sacra, LXI

124, julio-diciembre 2009, 649-690, ISSN: 0018-215-X 
De semejante tenor es el sentir de Francisco de la Cuesta, maestro tejedor de lienzos, quien «mirando a evitar todo pleito y discordia», urgía a sus parientes más próximos a repartir sus bienes «por iguales partes, sin pleito ni desazón alguna como corresponde y debe ser entre hermanos» ${ }^{81}$.

En las «Declaraciones» de las «Quentas y Particiones» de don Pedro Tomé, la $9^{a}$ se ocupa de resolver jurídicamente esos problemas. «En Atención a cargarse [al clérigo] todo lo gastado en la Cortte Romana en el tiempo que se mantuvo en ella para la Consecución deel Arcedianatto y en la Expedición de las Bullas destta Dignidad y deel Beneficio de Almarza y Arziprestazgo de Melgar de Fernamental le deben luzir los frutos de dho Beneficio y Arziprestazgo, que entraron en la Casa deel difunto Dn Pedro Thomé por espacio de Doze a treze años, por lo que, y haber ocurrido insuperables dudas para apurar así el líquido ingreso como los gastos que en el mismo tiempo pudo Caussar el referido Arcediano en su manutención dentro de la Casa, con aquella dezenzia que hera regular, se ha Considerado que hademás de su hadaber se le debe Contribuir con Seis Mill rrs alzadamente y por una vez, cuia Cantidad le ha de dar $D^{a}$ Josepha Carrera anttes de entregar cosa alguna a los Interesados, sacándola deel hadehaber de cada uno a proporción»82.

Entre mediados de enero y finales de mayo de 1766, don Pedro Celestino se dedicó sin escrúpulos, y por vía judicial, a enturbiar las relaciones familiares con una aluvión de reclamaciones sobre las más nimias e irrelevantes cuestiones técnicas que enervaron los ánimos de su madre y hermanos. No es de extrañar que el clérigo fuera persona no grata entre los suyos. De hecho, desde poco después de su regreso de Roma, en 1755, había tomado una casa, propiedad del Cabildo catedralicio, la número 194, sita en la calle La Calera. Por 488 reales al año se había independizado e ido a vivir bastante lejos de su madre -que habitaba en la plazuela del Sarmental- y de su hermano -que ocupaba la mansión erigida por su padre en la calle de los Avellanos-. En ella residió hasta su muerte -paradójicamente en las inmediaciones del inmueble ocupado por los Iñigo de Angulo-83. El contraste entre intramuros -Sarmental y Avellanos- y extramuros -La Calera- materializa, de forma virtual, la ruptura entre el clérigo y el resto de su familia.

Aunque don Pedro Celestino era, no cabe la menor duda, un hombre hosco y problemático Tuvo, no obstante, buenas amistades en la ciudad. Descuella, en especial, el matrimonio conformado por don Lesmes Julián Toral Izquierdo,

81 AHPB. PN. Bernardo Alonso de Illera. Legajo 7189 (31 de marzo de 1764), folios 286-287. Véase F. J. SANZ DE LA HiguerA, «Testamentos, post-mortem, Catastro: un túnel del tiempo matrimonial para el artesanado burgalés» (2007) (en fase de redacción).

${ }^{82}$ AHPB. JM. Juan Antonio Fernández Guilarte. Legajo 977 (14 de julio de 1764), folio 260.

${ }^{83}$ ACCB. Libro de Redondo de 1755. Rentas de Casas. Nº 194 (La Calera). 
contador mayor de la Mesa Capitular de la Catedral de Burgos, y doña María Gertrudis de Villasana ${ }^{84}$. Tanto ella como él le señalaron como uno de sus testamentarios, cabezaleros y albaceas testamentarios -en el caso de ella como su «único testamentario»-. Doña María Gertrudis había trabajado en su casa -de hecho aún en su agonía (1773) le seguía llamando «mi Amo»- y le confió «la disposición de mi entierro, missas y sufraxios como todas las cosas», así como un encargo muy especial, que «atienda y mire por $D^{a}$ Manuela de Villasana mi hermana y por el citado Dn Lesmes (...) mi Marido». Sin duda, don Pedro Celestino sabía rodearse de personas con acceso fácil a mucho dinero y con mucho poder económico y fáctico. Doña María Gertrudis instituyó al arcediano como su albacea y su único y universal heredero ${ }^{85}$.

La deuda de gratitud para con el clérigo era inmensa, y excedía la de una mera relación laboral entre una criada, o una ama de llaves, y contratante ${ }^{86}$. Al poco de contraer matrimonio con don Lesmes, a doña María Gertrudis don Pedro Celestino le entregó 4.922 reales -2.750 cuando recibió la herencia de su padre, don Pedro Tomé, 1.200 reales «que dho Señor la dio para aiuda de pagar la renta de la Casa, que yo estava debiendo desde el año de mill Setecientos y Cinquenta y ocho hasta el de mill Setezienttos Sesenta y tres, ambos inclusive, que Contrajo dho Matrimonio que son seis años» 87 y 972 1/2 reales «que en varias ocasiones entregó dho Señor a la referida $D^{a}$ María Gertrudis». Esas cantidades sirvieron «para más aumento de su Dote y de sus Hijos»-que, exceptuando el desembolso en las rentas de la casa, fueron utilizadas para adquirir

${ }^{84}$ AHPB. PN. Jacinto Álvarez. Legajo 7121/1 (13 de octubre de 1769), folios 259-260. Don Pedro Celestino entregó a doña María Gertrudis 4.922 ำ reales.

${ }^{85}$ AHPB. PN. Jacinto Álvarez. Legajo 7118/1 (6 de septiembre de 1763), folio 233. Doña María Gertrudis calificó a don Pedro Celestino como «mi Amo», sea porque había ejercido como criada en su casa antes de su casamiento con don Lesmes Julián o por otras oscuras razones. El arcediano aparece siempre rodeado de mujeres en, a mi entender, muy extrañas circunstancias.

${ }^{86}$ Aunque son lamentablemente pocos en número, los testamentos que se han recopilado de criados y criadas nos dan abundantes pistas de su parecer y estrategias en vida y al encarar la muerte. En todos ellos, el «Amo», el contratante de sus servicios domésticos, era señalado como albacea o testamentario y en algunos se les designa como herederos universales. Dos ejemplos patentizan estos asertos. Valentín de Atienza determinó que su «Amo» Francisco Tristán fuera uno de sus 2 albaceas y que «mediante no tener, como no tengo Herederos forzosos, dexo, nombro e instituio por mi Único y Unibersal Heredero (...) a mi Amo»- AHPB. PN. Jacinto Álvarez. Legajo 7118/1 (7 de febrero de 1763), folio 40 -. María Bernal hizo lo propio con don Miguel de Páramo, «mi Amo», si bien sus pertrechos eran escasos «mediante hallarme sin Vienes algunos muebles ni raízes» - AHPB. PN. Joaquín de Noguerado. Legajo 7105/2 (2 de marzo de 1757), folio 234.

87 AHPB. PN. Jacinto Álvarez. Legajo 7121/1 (13 de octubre de 1769), folios 259-260. don Lesmes Julián era bastante problemático en lo tocante al pago de las deudas. A lo señalado para el alquiler de la casa se añaden sus impagos a un mercader de la ciudad, en concreto 800 reales «que yo le estaba deviendo de varios géneros que havía sacado de su tienda antes de Contraer dho Mattrimonio». Estas segunda nupcias le ayudaron a superar muchas adversidades. Fueron unos esponsales providenciales, y con clérigo al fondo.

Hispania Sacra, LXI

124, julio-diciembre 2009, 649-690, ISSN: 0018-215-X 
«un Cascabelero y Campanilla de platta para los Niños [2 hijos], Cinco Cubiertos de lo mismo que están gravados con el Apellido de Villasana, un Cavo de Cuchillo, un Salero, azucarero y pimentero también de plata, dos Sortijas de Oro, unos granos de lo mismo que mandó hechar de trecho en trecho al Collar de Aljófar que está puesto en la Escritura de Dote y Arras, se pagaron también los tauretes, Sitiales y Mesa Redonda que se compraron en Casa del Señor Conde de Villariezo, los Seis Tauretes de Baqueta nuevos y friso de Varios Colores que se hallan en el Quarto como también una Paila grande de frusleda que se compró a $D^{a}$ Thomasa Aldamez, vecina viuda de esta Ciudad»88_.

El afectoque se percibe en las últimas voluntades de su antigua sirvienta no era paralelo al sentimiento de sus propios familiares directos, si bien tales circunstancias no son de extrañar. En los testamentos de don Pedro Tomé y doña Josefa Carrera todo son parabienes para Antonio y una absoluta ausencia del huido Juan Manuel y del ofuscado e intratable Pedro Celestino. El «cobdicilio» de Pedro Tomé sintetiza sus predilecciones y olvidos. "Usando deel derecho, que por las Leies de esttos Reinos le está Comedido, y por el mucho Amor y Cariño que tiene y profesa a Dn Anttonio Thomé Carrera (...) le mandaba y mando el tercio de todos los Vienes y Hacienda muebles y Raíces, derechos y Acciones que ttiene y le pertenecen y le quedaren a el tiempo de su fin y muerte en el qual terzio mejoraba y mejoró desde luego a el referido Dn Antonio» ${ }^{89}$.

En las últimas voluntades rubricadas en 1771 por doña Josefa se explicita que «En Attención a que mi Hijo Dn Anttonio Thomé es quien lleba la Casa y Negocios y que después que falleció mi Marido y su Padre dn Pedro ha asistido con puntualidad y amor a todos los que me han ocurrido, trabajando Extraordinariamente y con el deseo de que en algún modo se le recompensen sus tareas y que pueda manttener el honor, Créditto y reputación de que su Padre se hizo Acreedor en el Jiro de las dependencias que esttubieron a su Cargo (...) le mejoro en el terzio y remanente deel Quinto de todos los Bienes y Efectos que dejare, pagándosele su importte en lo mejor y más bien parado de ellos a su Elección o bien en la Cabaña deel Ganado Merino trashumante que manttengo o en plata, Hazienda Raíz y dinero efectivo, sin que sobre estto se admitta disputta ni Contienda de Juicio, aunque las inttenten los demás Herederos» ${ }^{90}$.

Doña Josefa repartió mandas para todos sus allegados -su hermana Francisca, sus nietos, los trabajadores del lavadero, el personal doméstico de servicio en la casa, etc.-. Al eclesiástico únicamente le nombró, pero en compañía de su hermano don Antonio, del abad de Cobarrubias y del lectoral de la Catedral, cabezalero, testamentario y heredero. La herencia se la repartirían entre don Anto-

\footnotetext{
${ }^{88}$ AHPB. PN. Jacinto Álvarez. Legajo 7121/1 (13 de octubre de 1769), folios 259-260.

${ }^{89}$ AHPB. PN. Juan Antonio Fernández Guilarte. Legajo 7029 (14 de junio de 1764), folio 431.

${ }^{90}$ AHPB. PN. Alonso de Melo Peña. Legajo 7208/2 (27 de febrero de 1771), folio 82.
} 
nio, don Pedro Celestino y don Francisco Tomé, su nieto, hijo de su difunto Fernando -a quien previamente le había obsequiado, «pendiente sólo deel Amor que le tengo», con 2.000 ducados "para aiuda de Acomodarse o Colocarse en el Esttado que Elijiere»91. A don Pedro Celestino nada más que lo estrictamente obligado por ley.

Lo que se siembra se recoge. Mejor suerte tuvieron, por ejemplo, don Francisco Sainz de Viniegra, prebendado en la Santa Iglesia Metropolitana, fiscal general eclesiástico de ella y su Arzobispado, y don Pedro, su hermano, abogados ambos de los Reales Consejos, a quienes «les hemos asistido de todo lo necesario para sus estudios mayores, Cursos, Grados, oposiciones que hizo Dn Francisco a la Doctoral de Palenzia -afirmaba su padre, don Francisco ${ }^{92}$, viaje a Madrid y demás, manteniéndolos en sus estancias en esta Ciudad y en nra Casa (102), en que hemos suplido Crecidas porziones y en vestirlos y Compra de Libros, que uno y otro con separazión y distinción resulta del Libro de quenta y razón que llebamos de lo que Gastamos y entregamos a estos y demás nros hijos, es nra voluntad que lo que respectibamente Corresponde a cada uno se les considere como rezibido en quenta de lo que les pueda tocar por nras lexítimas (...) para que ninguna suerte se verifique perjuizio (...) atendiendo a el Cariño y Amor Paternal que les tenemos y a que nos an correspondido con Igual Afecto como buenos hijos ${ }^{93}$. El contraste entre un hogar y otro no ofrece la más mínima duda.

En el testamento de 1778, doña Josefa ratifica el anterior documento pero añade una cláusula específica para el hijo clérigo. Le mandaba varios menajes de mesa (cucharas, tenedores, salvillas y bandejas de plata) y de cama «con $\mathrm{Ca}$ lidad de que no mueba ni Cause disensiones ni disputas entre mis Herederos, pues si se verificase ha de entender nula esta manda (...) esperando de dho hijo don Pedro Celestino procurará observar la mejor armonía con los demás Coherederos, su hermano y sobrino» ${ }^{94}$. El palo y la zanahoria elevadas al rango de catálogo de conducta.

Es probable que don Pedro Celestino conociera y tal vez incluso hubiera leído «La vida de Lazarillo de Tormes y de sus fortunas y adversidades» ${ }^{95}$. El sufrido Lázaro de mediados del XVI y el torturado Arcediano catedralicio de mediados del XVIII hermanados, y agobiados, por la paternidad de Tomé

91 AHPB. PN. Alonso de Melo Peña. Legajo 7208/2 (27 de febrero de 1771), folio 81.

92 AHPB. PN. Francisco de Villafranca. Legajo 7094 (28 de abril de 1761), folio 601602. Véase F. J. SANZ DE LA Higuera: «Clérigos a la sombra de un pariente en el XVIII burgalés», Hispania Sacra, 120 (2007), Madrid, pp. 563-594.

93 AHPB. PN. Francisco de Villafranca. Legajo 7094 (28 de abril de 1761), folio 601-602.

94 AHPB. PN. Francisco de Villafranca. Legajo 7101 (22 de enero de 1778), folio 14.

95 Utilizo la versión publicada por EL PAÍS, Barcelona, 2005.

Hispania Sacra, LXI

124, julio-diciembre 2009, 649-690, ISSN: 0018-215-X 
González. El uno inmensamente pobre y desheredado; el otro abrumadoramente opulento y poderoso. Ambos, en algunos de los episodios de sus existencias, estuvieron angustiados bajo la férula de algún clérigo y de, según sus versiones, sus brutales castigos y exigencias. En el carácter enfermizo y en ocasiones brusco del arcediano de Burgos también influía una afección que compartía con su progenitor, la podagra - una de las manifestaciones de la gota- que tendría el dedo gordo del pie del clérigo con un continuo dolor en la articulación metatarsofalángica, patología que le irritaba habitualmente y le hacía encolerizarse con facilidad.

Dejando a un lado a los controvertidos Tomé y la exquisitez de los Iñigo de Angulo, nos centraremos fugazmente en otro de los jueces capitulares, don Miguel Jerónimo Méndez. En 1781, fue objeto de una demanda por parte de Baltasara Pacheco, su ama de llaves durante un par de años (1778-1780). Sebastián Ochoa y Marieta, maestro ebanista, su cónyuge, y la susodicha Baltasara, llevaron a los tribunales al clérigo, acusado de fraude en la «liquidazión de Cuenta del tpo que fue su Criada» ${ }^{96}$. La judicialización de la vida cotidiana llevada a casa del juez eclesiástico.

\section{¿ERA DON FELIPE DEL HOYO UN CLÉRIGO HONESTO (1731-1751)? UNA SOSPECHOSA PRESENCIA EN CASA DEL ARCEDIANO DE BURGOS}

Don Felipe del Hoyo Santamaría era canónigo desde diciembre de 171997. En marzo de 1731 se hizo con la coadjutoría del arcedianato de Burgos, cuya titularidad le fue conferida el 11 de abril, dieciséis días antes del óbito de don Diego de Lerma y Salamanca. Sus muchos achaques físicos le imposibilitaron continuar en servicio del Cabildo y cumplir honradamente con la residencia, patologías que le decidieron a entregar la dignidad que gozaba a un canónigo de reconocida calidad humana y religiosa. Falleció el 28 de marzo de $1731^{98}$.

El 13 de noviembre de 1750 exhaló don Felipe su último suspiro, a las seis y media de la tarde. De ello se beneficiaron dos personas. Por una parte, don Manuel Real Varona, que recibió el canonicato ${ }^{99}$, y don Pedro Celestino Tomé Ca-

96 ACCB. Libro 135. «Demanda de Baltasara pacheco al Sor Dn Miguel Méndez, Canónigo sobre liquidazión de Cuenta del tpo que fue su Criada» (1781), folios 1-114. Véase M. ORTEGA LóPEZ, «Estrategias de defensa de las mujeres de la sociedad española del siglo XVIII», Arenal. Revista de historia de las mujeres», 5/2 (1998), pp. 277-305 y E. GACTO FERNÁNDEZ, «Entre la debilidad y la simpleza. La mujer ante la ley», Historia 16, 145 (1988), pp. 24-32.

97 ACCB. Diversos. Libro 39. Posesiones SIM: entrada/salida de prebendados (1728-1892), 31 de marzo de 1721. Véase A. Blanco DíEz (1952), pp. 290.

98 ACCB. Diversos. Libro 39. Posesiones..., 12 de marzo de 1731 (coadjutoría) y 11 de abril de 1731 (titularidad). Cfr. A. BLANCo DíEz (1952), pp. 289-290.

${ }^{99}$ ACCB. Libro 116, 11 de junio de 1751, folios 661-662. 
rrera, a quien se adjudicó, como sabemos, el arcedianato. Don Felipe, bastante más previsor, consciente y responsable que su sucesor en la dignidad, rubricó un testamento ${ }^{100}$ que es una joya histórica. Con sus pertrechos y propiedades se elaboró un inventario post-mortem que nos dice mucho de sus maneras de vivir $\mathrm{y}$ de morir ${ }^{101}$.

Entre las órdenes de don Felipe descuella aquella en la que señala «Mando se dé a $D^{a}$ Josepha de Tapia, que se alla en mi compañía, un luto como a todos los demás Criados que al tpo de mi fallezimiento esttén en mi Casa según la clase de Cada Uno». ¿Había más sirvientes en su hogar? Al parecer, según se desprende del testamento, estaban solos. ¿Cuál era el papel desempeñado por doña Josefa? En general, en las últimas voluntades del clero se expresa el agradecimiento, y aún el afecto, por todas y cada una de las criadas de forma particular ${ }^{102}$. En el devenir de la enfermedad y agonía que le llevó a la muerte, esa mujer se convirtió en protagonista estelar de sus postreras decisiones como lo había sido en los 28 años que sirvió en el hogar de don Felipe. ¿Qué se debe entender de la frase « $D^{a}$ Josepha de Tapia (...) se alla en mi Compañía asistiéndome con todo afecto y Cariño? ${ }^{103}$.

Doña Josefa traía la despensa y era la encargada de las llaves de la casa. «La simbología de las llaves reflejaba -en palabras de la profesora Candau Chacónuna situación de usurpación de papeles y de dominio: sobre el espacio familiar, sobre los bienes y sobre el falso marido. También, en buena lógica, sobre los afectos»104. No existen evidencias escritas de trato carnal ni se pueden lanzar acusaciones fundadas de amancebamiento. Es presumible la sospecha de una relación que excedía lo puramente profesional entre el clérigo y la sirvienta. En Coria, el $80.3 \%$ de los delitos contra la moral sexual eran amancebamientos entre clérigos y mujeres, consecuencia de un celibato impuesto y mal llevado o de un enamoramiento incuestionable. Era una conducta muy extendida, aceptada por la sociedad, «ya que si no fuera así ésta habría generado los mecanismos necesarios para atajarla»105.

${ }^{100}$ AHPB. PN. Diego Fernández de Cormenzana. Legajo 7081 (15 de enero de 1750), folios 182-185.

101 Véase F. J. SANZ DE LA HigUERA (2005b), pp. 215-245, «La temible f(r)actura de la muerte. Fallecer en el Burgos del Setecientos», Cuadernos de Investigación Histórica, 23 (2006), pp. 252-283 y (2007) «Aristocracia eclesial «en carrera de salbación». Las dignidades catedralicias burgalesas entre la vida y la muerte a mediados del Setecientos», Cuadernos de Investigación Histórica, 24, pp. 355-413.

102 Véase F. J. SANZ DE LA Higuera (2006a), pp. 545-577. Se encuentra en proceso de redacción «Salarios in articulo mortis». El servicio doméstico en los hogares eclesiásticos burgaleses de mediados del siglo XVIII» en el que se dará cuenta de las estrategias de los diferentes clérigos a la hora de atender, mantener y pagar sus emolumentos a las amas de llaves y criadas que tenían contratadas.

${ }^{103}$ AHPN. PN. Diego Fernández de Cormenzana. Legajo 7081 (15 de enero de 1750), folio 183.

104 M. L. CANDAU Chacón (2002), pp. 403-432.

${ }^{105}$ S. ARAGÓN Mateos (1992), pp. 291-334.

Hispania Sacra, LXI

124, julio-diciembre 2009, 649-690, ISSN: 0018-215-X 


\begin{tabular}{|c|c|c|c|c|c|c|c|c|c|c|c|c|c|c|c|c|c|c|c|c|c|c|c|}
\hline \multirow{13}{*}{ 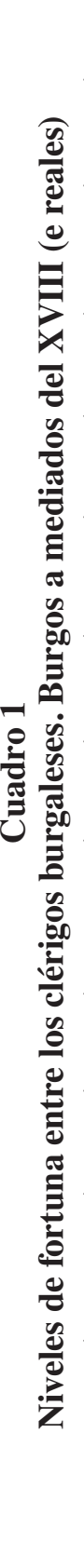 } & $\underset{0}{0}$ & ț. & $\stackrel{0}{\sim}$ & $\left|\begin{array}{c}\infty \\
\dot{\sim}\end{array}\right|$ & $\exists$ & ชై & $\exists$ & 9 & $\vec{m}$ & $\stackrel{\pi}{\sim}$ & $\begin{array}{l}\dot{0} \\
\dot{0}\end{array}$ & $\stackrel{-}{\infty}$ & $\begin{array}{l}\circ \\
\circ\end{array}$ & - & & $\because$ & $\overrightarrow{\dot{\nabla}}$ & $\stackrel{\sim}{-}$ & & & & 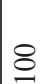 & \\
\hline & $\underset{0}{0}$ & $\tilde{i}$ & $\vec{i}$ & $\stackrel{?}{-}$ & $\stackrel{\stackrel{\sim}{*}}{-}$ & $\stackrel{\sim}{i}$ & $\grave{m}$ & $\stackrel{0}{0}$ & $\exists$ & $\tilde{i}$ & ठே. & $\vec{m}$ & $\stackrel{\nabla}{\dot{r}}$ & $\because$ & $\begin{array}{l}2 \\
\infty \\
0\end{array}$ & $\stackrel{n}{\sim}$ & $\vec{\nabla}$ & $\stackrel{+}{0}$ & $\stackrel{2}{\check{2}}$ & స్ & 9 & 8 & \\
\hline & 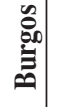 & $\underset{\substack{\infty \\
\stackrel{\infty}{-}}}{ }$ & $\stackrel{\check{n}}{\stackrel{n}{-}}$ & \begin{tabular}{|l|}
$\infty$ \\
$\infty$
\end{tabular} & ๙ે & 告 & 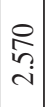 & 䙳 & $\stackrel{2}{2}$ & 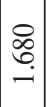 & $=$ & 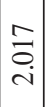 & 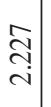 & $\stackrel{\infty}{~}$ & 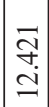 & 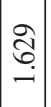 & $\begin{array}{l}\text { 导 } \\
\stackrel{+}{+}\end{array}$ & బి & \begin{tabular}{l}
$\infty$ \\
0 \\
0 \\
\hdashline \\
$=$
\end{tabular} & 尺̊ & స్ & $\frac{0}{\stackrel{2}{2}}$ & : \\
\hline & $\begin{array}{c}\overparen{a} \\
\dot{0}\end{array}$ & $\stackrel{f}{=}$ & $\stackrel{9}{=}$ & $\stackrel{+}{0}$ & $\vec{n}$ & $\begin{array}{l}n \\
\infty\end{array}$ & $\stackrel{\Xi}{\mathrm{I}}$ & $\stackrel{n}{i}$ & $n$ & $\stackrel{\infty}{-}$ & $\mid \begin{array}{l}\infty \\
\stackrel{0}{0} \\
0\end{array}$ & 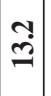 & $\stackrel{\forall}{*}$ & $\stackrel{\sim}{\sim}$ & & $\left|\begin{array}{l}\infty \\
\alpha\end{array}\right|$ & & 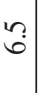 & & & & 8 & $\widetilde{\sigma}$ \\
\hline & $\underset{0}{0}$ & $\stackrel{\bullet}{+}$ & $\stackrel{\sim}{\sim}$ & $\overrightarrow{0}$ & $\vec{i}$ & $\stackrel{\sim}{m}$ & $\stackrel{\partial}{\dot{\gamma}}$ & 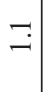 & $\tilde{\sim}$ & $\tilde{0}$ & 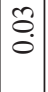 & $\begin{array}{c}n \\
i \\
i n\end{array}$ & $\vec{i}$ & 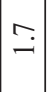 & $\begin{array}{l}\infty \\
\stackrel{1}{c}\end{array}$ & $\stackrel{\infty}{\infty}$ & & $n$ & $\ddot{\vec{i}}$ & ڤે) & & 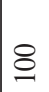 & อ. \\
\hline & 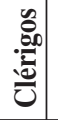 & $\stackrel{2}{\curvearrowleft}$ & $\underset{\widetilde{\sigma}}{-}$ & $\tilde{n}$ & वे & $\begin{array}{l}9 \\
= \\
=\end{array}$ & $\mid \begin{array}{l}0 \\
0 \\
0 \\
- \\
-\end{array}$ & f & $\begin{array}{l}2 \\
\infty \\
\infty \\
\infty\end{array}$ & 竎 & $\simeq$ & 蚉 & $\approx$ & $\bar{n}$ & $\begin{array}{l}\vec{O} \\
\dot{q} \\
\dot{q}\end{array}$ & 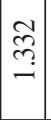 & & $\begin{array}{l}2 \\
\infty \\
\infty \\
\infty\end{array}$ & $\underset{I}{\Xi}$ & 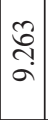 & & $\begin{array}{l}\mathscr{2} \\
m \\
m \\
m\end{array}$ & $\begin{array}{l}\frac{5}{0} \\
\frac{\pi}{0}\end{array}$ \\
\hline & ạ & $m_{\infty}$ & $\approx$ & תִ & $\stackrel{\sim}{\sim}$ & 7 & $\stackrel{+}{\infty}$ & $\stackrel{?}{-}$ & $\stackrel{\vartheta}{+}$ & $\vec{i}$ & $\stackrel{\dot{0}}{0}$ & \begin{tabular}{|l|} 
\\
\pm \\
\end{tabular} & $\stackrel{n}{r}$ & 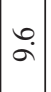 & & $\underset{\infty}{\infty}$ & & 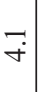 & & & & 8 & $\theta$ \\
\hline & $\underset{\infty}{O}$ & $\stackrel{m}{m}$ & \begin{tabular}{|c|}
$\infty$ \\
$\stackrel{\infty}{*}$
\end{tabular} & $\mid \begin{array}{l}5 \\
0 \\
0\end{array}$ & $\stackrel{6}{-}$ & $\stackrel{\vec{i}}{\mathrm{i}}$ & $\stackrel{m}{r}$ & $\ddot{n}$ & 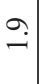 & \begin{tabular}{|c|} 
\\
0 \\
0
\end{tabular} & $\begin{array}{l}\tau \\
0 \\
0\end{array}$ & in & $\vec{i}$ & \begin{tabular}{|c|}
$\infty$ \\
$\stackrel{\infty}{*}$
\end{tabular} & & $\stackrel{n}{m}$ & & $\stackrel{0}{.}$ & $\vec{m}$ & $\begin{array}{l}n \\
n \\
n\end{array}$ & & 8 & \\
\hline & 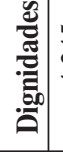 & $\underset{\stackrel{\mathfrak{q}}{\mathrm{f}}}{\stackrel{f}{+}}$ & $\mid \begin{array}{c}\tilde{V} \\
\infty \\
\dot{+} \\
+\end{array}$ & œ & $\mid \begin{array}{c}\tilde{n} \\
\end{array}$ & $\begin{array}{c}\stackrel{0}{\prime} \\
\dot{m} \\
\end{array}$ & $\left|\begin{array}{c}\hat{n} \\
\tilde{a} \\
\sigma\end{array}\right|$ & ถి & 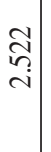 & 每 & $\vec{\sim}$ & 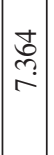 & $\begin{array}{l}\dot{J} \\
\infty \\
\dot{\sim} \\
\end{array}$ & $\mid \begin{array}{c}2 \\
\infty \\
+ \\
+\end{array}$ & & 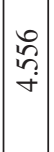 & & $\begin{array}{l}\infty \\
\stackrel{1}{0} \\
\end{array}$ & 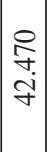 & $\begin{array}{l}0 \\
6 \\
\vdots \\
0 \\
=\end{array}$ & & 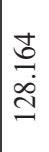 & 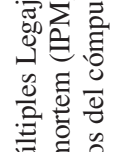 \\
\hline & $\begin{array}{c}\overparen{a} \\
0^{\circ}\end{array}$ & $\stackrel{?}{\varrho}$ & فे & $\begin{array}{l} \pm \\
0 \\
0\end{array}$ & m & $\stackrel{+}{\stackrel{2}{2}}$ & in & $\vec{i}$ & $\vec{a}$ & ִֻ & & בุ: & $\stackrel{n}{+}$ & $\because$ & & $\dddot{m}$ & & $?$ & & & & \& & 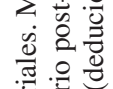 \\
\hline & $\underset{\infty}{O}$ & $\overrightarrow{0}$ & $\overrightarrow{0}$ & $\begin{array}{l}0 \\
0 \\
0\end{array}$ & लె! & $\underset{\infty}{\infty}$ & $\stackrel{\Delta}{a}$ & $\stackrel{\sim}{\longrightarrow}$ & $\stackrel{+}{\dot{n}}$ & : & & $\mid$ & $\vec{i}$ & $\stackrel{\substack{f \\
\sim}}{ }$ & & $\left|\begin{array}{l}\infty \\
0 \\
0\end{array}\right|$ & & $\dddot{n}$ & & $\overrightarrow{\dot{f}}$ & & \& & $\begin{array}{l}\overline{0} \\
\tilde{0}\end{array}$ \\
\hline & 量 & 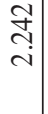 & $\mid$ & 으 & 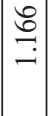 & $\left|\begin{array}{l|}\infty \\
\tilde{i} \\
\end{array}\right|$ & $\begin{array}{c}\tilde{y} \\
\stackrel{f}{r}\end{array}$ & $\hat{\Im}$ & $\begin{array}{l}\infty \\
\stackrel{2}{\circ} \\
\stackrel{-}{-1}\end{array}$ & $\ddot{m}$ & & $\left|\begin{array}{l}\hat{0} \\
\infty \\
i\end{array}\right|$ & 豙 & $\mid$ & & ষ্লি & & $\cong$ & & 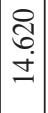 & & $\begin{array}{l}\infty \\
\stackrel{\infty}{+} \\
\stackrel{0}{\sim}\end{array}$ & $\stackrel{2}{2} \stackrel{0}{0}$ \\
\hline & & 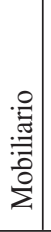 & 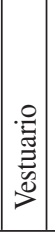 & 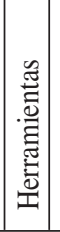 & 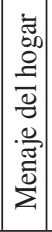 & 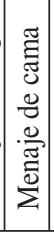 & 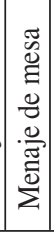 & 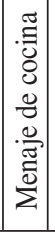 & 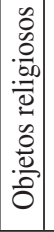 & 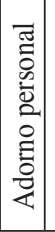 & 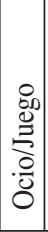 & 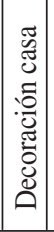 & 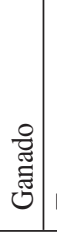 & 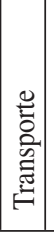 & 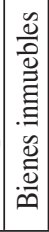 & 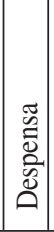 & 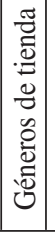 & 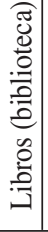 & 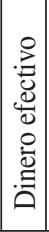 & 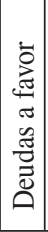 & 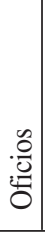 & 퓽 & 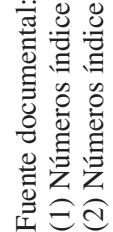 \\
\hline
\end{tabular}


El inventario post mortem del arcediano de Burgos computó pertrechos y propiedades por un montante ligeramente superior a los 36.000 reales ${ }^{106}$. El $40.1 \%$ correspondían a las percepciones de sus prebendas anuales en el Cabildo catedralicio -véase el CUADRO I-. Don Felipe era un más que modesto canónigo y dignidad de la Catedral, que vivía muy por debajo del promedio de fortuna de los otros capitulares 107 . Su confort eran escaso, semejante a los del clero medio. No obstante, el atrezzo de su vivienda en lo tocante a menajes de mesa y cama así como la cantidad y calidad de su mobiliario y vestuario y la disponibilidad de carruaje le daban una cierta pátina de respetabilidad privilegiada, aunque tampoco excesiva ${ }^{108}$.

Don Felipe señaló como heredero universal, puramente funcional, protocolario y aparente, de sus bienes y hacienda al canónigo don Diego de Castro y Figueroa,. Añadió, sin embargo, "sólo se ha de entender como fideicomisario y con la condizión de que todo lo que ymporte el remanente de ellos, deduzidas las mandas y legados que ban referidas (...) lo reziba y ponga por bía de depósito en el Archibo de tres llabes del Combentto de San Pablo». Tales caudales serían invertidos en la compra de bienes raíces o en la concesión de censos para que lo que redituare se entregara a sus sobrinas, hijas de su hermano don Juan Isidoro, monjas profesas en un convento de la ciudad "para que con ello se puedan socorrer en sus necesidades». Sus testamentarios y cabezaleros, el citado hermano, los miembros del Cabildo catedralicio don Diego Zamora Huidobro, don Diego de Castro y Figueroa y don Francisco de la Peña, a quienes se sumaba expresamente doña Josefa de Tapia, debían tomar sus bienes y venderlos, con las excepciones hechas por don Felipe, en pública almoneda para satisfacer sus deseos y mandas. Previamente, se habían apartado 5.388 reales para don Juan Isidoro (un $14.8 \%$ de sus bienes).

Don Felipe ordenó se entregara a su ama de llaves lo siguiente:

«Onze mil rrs Vellón por Una Vez Comprendiéndose en ellos y por pagados los Salarios que la he devido Contribuir en Veinte y ocho años que a que esttá en mi Compañía, que no ha de poder pedir, solo si se los debengare astta que yo fallezca estando en mi Casa al Respectto de Veintte ducados cada año (102); y además la mitad de toda la ropa Blanca que quedare al ttpo de mi fallecimiento; Una salbilla de plata de peso de Veintte onzas poco más o menos; Una bandeja de lo mismo en ttreintta onzas; Un salero Azucarero y pementtero de plata; dos cucharas y dos tenedores ttambién de plata; Un Cattre

\footnotetext{
106 AHPB. PN. Diego Fernández de Cormenzana. Legajo 7081 (21 de noviembre de 1750), folios 280-291.

107 Véase L. C. Álvarez SANTALó (2000), pp. 139-145. El promedio de 142 inventarios post-mortem del clero sevillano era de 69.920 reales. Cfr. también J. Bravo LozANo (1994), pp. 129-139.

108 Cfr. L. C. Álvarez Santaló (2000), pp. 118-119, 121 y 144-145 y F. J. Sanz de La Higuera, «Una estancia doméstica que se mueve...», Cuadernos de Investigación Histórica, 21 (2004), Madrid, pp. 469-506. El coche era el más caro de los muebles de la casa eclesiástica.
}

Hispania Sacra, LXI

124, julio-diciembre 2009, 649-690, ISSN: 0018-215-X 
con su pabellón de paño, seis Colchones de los mejores, seis mantas de las que quisiere escoger; Todos los quadros que ttiene y adornan su quartto con un Santto Xptto que ttiene a la Cabezera de su Cama; dos Camas de Bilbao y de Ibierno, dos colchas blancas, seis taurettes y seis sillas a su elección; Una papelera grande con su mesa, pintada dha papelera; Una mesa redonda dada de Charol, dos escripttorios de Concha con sus mesas; Una nra Sra de la Concezión con su marco dorado, tres quadros Correspondienttes con las efigies de San Antonio de Padua, San fernando y el ottro de San Antonio Abad y San Pablo; Un Arcón de nogal de Vara y quartta de largo, dos cofres, el uno forrado en encarnado y el ottro de negro; un quadro con su marco dorado y de Cristales de poco más de una Terzia con la efigie de nra Sra de Méjico; Una Caja de Brasero Clabettiada de Bronze con su payla y paletta correspondiente y lo que necesitase de Cocina para su Uso y abittazion y que quisiere elegir, como ttambién todas las esteras y felpudos que tuviere la Casa, dos Cujas Con sus pajeros, dos Cobertores de Blanquetta azul; Una docena de platos de pelttre y ttodo el bidrio y vidriado que quedare; y la mitad de ttodo el alimentto Comestible y Chocolate que dejare y más Seis Corttinas de Bayeta para puerttas, benttanas y alcobas, y ottras seis de berano, y no se la rejisttre Cofres ni Arcón alguno que ttubiere ni se la pida quentta de Nada sino de la que quisiere dar por la mucha Sattisfazion y Confianza que ttengo de la suso dha, Xpistiandad y Realidad que profesa; Y ttodo lo referido se la de estté o no en mi Casa y Compañía al ttiempo de mi fallecimiento» ${ }^{109}$.

He parafraseado todas sus palabras para impactar al lector con la magnitud del legado. Quienes conocen bien, para el Antiguo régimen y en concreto para el Setecientos, las últimas voluntades de los clérigos, e incluso de la mayoría de los laicos, saben que en ellos se señala una «Cama completa» y el abono de los salarios no satisfechos, y poco más, en el capítulo de las menciones a las criadas pero sin las dimensiones del aquí citado párrafo.

En el inventario post mortem se especifican de una forma puntual y extrañamente inusual -de hecho, de entre los 60 IPM recopilados para clérigos es el único en que sucede dicha circunstancia- los «Trastos del Quartto que habitaba $D^{a}$ Jpha de Tapia», cuya descripción comienza, sin mediar más palabras, con la mención a «Un Cattre de haya dado de encarnado»110. ¿Fueron 28 años de insípida y distante relación laboral o hubo algo más? No se puede manchar impunemente la memoria de ninguno de ellos pero da la impresión de que el arcediano trató a su ama de llaves como a una persona que había compartido con él bastante más que las sillas y las mesas. Hubo cónyuges en el Antiguo Régimen que obtuvieron un trato bastante peor que dicha mujer ${ }^{111}$. Empero, había

109 AHPB. PN. Diego Fernández de Cormenzana. Legajo 7081 (15 de enero de 1750), folios 183 184. Véase López López (1989), SÁNCHEZ GonZÁlez (1998), IrigOYEN LóPEZ (2007), AraGón MATEOS (1990), GONZÁlez CRUZ (19) y QuinTANA ANDRÉs (2005 y 2006).

110 AHPB. PN. Diego Fernández de Cormenzana. Legajo 7081 (24 de noviembre de 1750), folios 290-292.

111 Véase M. Ortega López (2006), pp. 7-37, M. J. DE La PAscua SÁnchez: «Violencia familiar en la España del Antiguo Régimen», Estudis, 28 (2003), pp. 77-100, T. A. MANTECón Movellán, «Mujeres forzadas y abusos deshonestos en la Castilla Moderna», Manuscrits, 20 (2005), pp. 157-185 y F. J. 


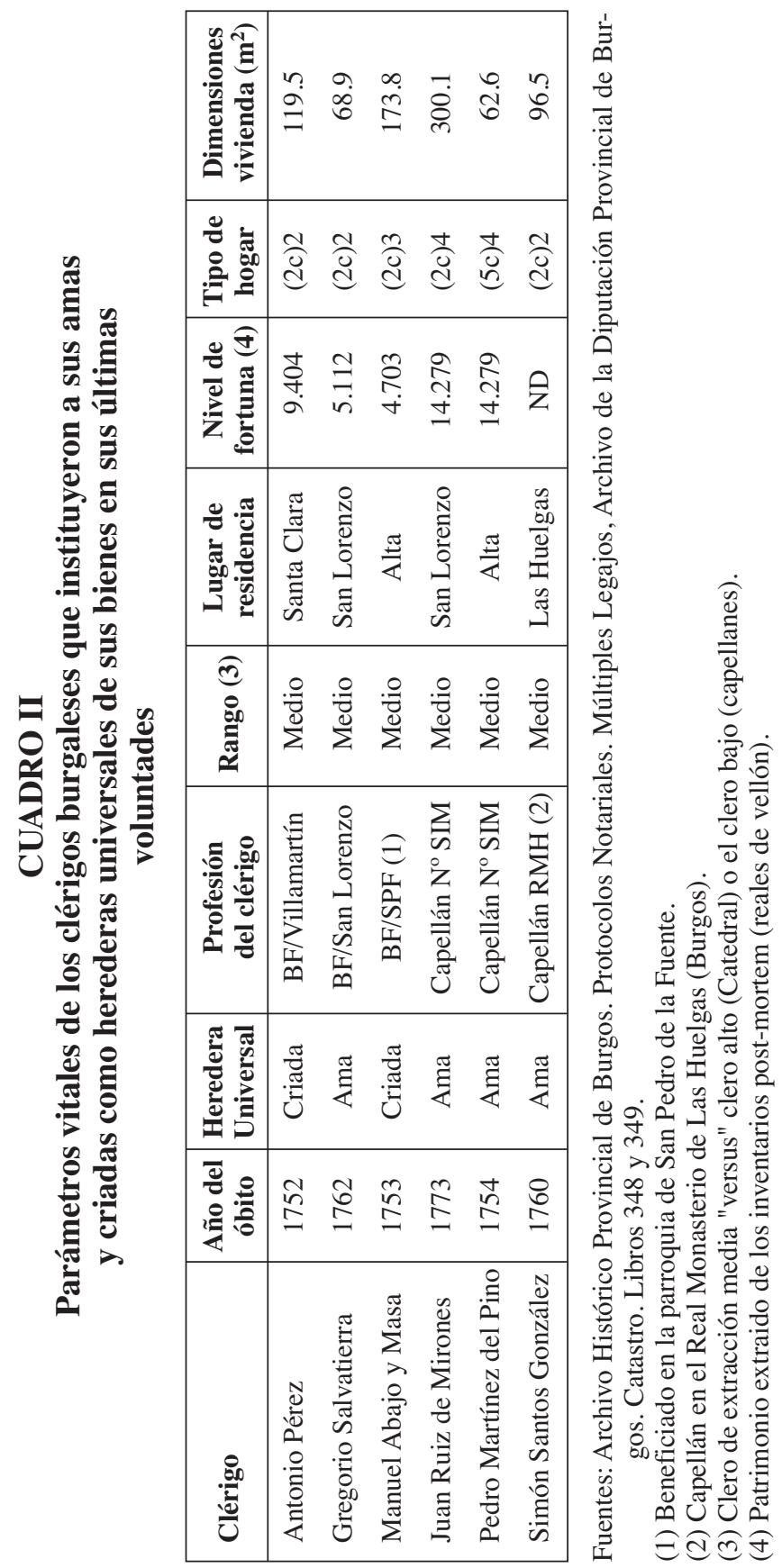

Hispania Sacra, LXI

124, julio-diciembre 2009, 649-690, ISSN: 0018-215-X 
que guardar las formas. Evidentemente, si don Felipe de Hoyo hubiera señalado a doña Josefa como su heredera universal ello habría generado, con bastante probabilidad, los más ruidosos y acerados comentarios críticos, las murmuraciones más agrias y acusadoras.

El $4.8 \%$ de los 126 testamentos recopilados para eclesiásticos residentes en Burgos a la hora de elaborar el Catastro de Ensenada dejaron al ama o a la criada como heredera universal de sus bienes -véase CUADRO II-. Fueron las amas de llaves las señaladas con una mayor proporción, el $66.7 \%$, mientras que a las criadas únicamente les cupo un $33.3 \%$ de las herencias. Don Antonio Pérez ${ }^{112}$ nombró a su criada Clara González como testamentaria y heredera universal, a pesar de tener entre sus deudos a varios hermanos y sobrinos. Algo similar ocurre en las últimas voluntades de don Manuel Abajo y Masa113. Don Gregorio de Salvatierra114 instituyó a Gertrudis Izquierdo, su Ama, como universal heredera, «en atención a la buena asistencia y Cuidado con que me a servido en más de quince años y asistido en todo quanto a estado de su parte con especial ley». Don Juan Ruiz de Mirones ${ }^{115}$ hizo lo propio con Úrsula de Oña, «en atención a el buen servicio y cuidados que ha tenido y tiene de mi persona y Casa más de quarenta años a esta parte en concepto de Ama». Nos hallamos ante clérigos de rango medio y economías modestas, cuyos niveles de rentas y fortuna les permitían vivir con una relativa comodidad aunque sin excesivas alegrías. Sus hogares tenían una estructura sencilla -en el $83.3 \%$ de los casos se trataba de hogares sin estructura familiar en que el clérigo corresidía con una ó dos criadas- y unas dimensiones no excesivamente grandes -las casas que tenían arrendadas disponían de un promedio de $140 \mathrm{~m}^{2}$ de suelos habitables, cifra muy cercana a la media de la ciudad, $114 \mathrm{~m}^{2}$.

Las amas de llaves recibieron de los hombres con quienes habían compartido el espacio habitacional una parte substancial de sus fortunas y quedaron al albur de las circunstancias hasta su propio óbito'116. En noviembre de 1780, doña Josefa Tapia, soltera y agonizante -no pudo firmar sus últimas voluntades «por impedírselo la gravedad de su enfermedad»-, «dejó, nombró e ynstituyó por única y universal heredera a [su] Alma»117. A 30 años de distancia de la

SANZ DE LA HigUERA, «A la sombra de la muerte: Viudez espléndida, viudedad paupérrima a mediados del Setecientos», Cuadernos de Investigación Histórica, 22 (2005), pp. 431-461.

112 AHPB. PN. Juan Antonio Fernández Guilarte. Legajo 7018 (30 de noviembre de 1752), folio 478.

${ }^{113}$ AHPB. PN. Ángel Arnaiz. Legajo 7164 (12 de abril de 1753), folio 52.

${ }_{114}$ AHPB. PN. Bernardo Alonso de Illera. Legajo 7188 (28 de octubre de 1762), folio 666.

115 AHPB. PN. Bernardo Alonso de Illera. Legajo 7191 (4 de octubre de 1773), folio 222.

${ }^{116}$ Las mujeres que mantenían relaciones con clérigos, aunque éstas no fueran de índole sexual, tenían en la penuria económica y psíquica uno de los más graves condicionantes de sus existencias. Trabajar durante años sin percibir salario alguno las arrojaba a una dependencia brutal. Véase I. PÉREZ MuÑOZ (1992), pp. 59.

117 AHPB. PN. Rafael Pérez Romo. Legajo 7234 (10 de noviembre de 1780), folios 573-574. 
muerte de don Felipe del Hoyo, doña Josefa no sabía literalmente donde meter su cuerpo. En el testamento indicó que fuera sepultado en el Colegio de carmelitas descalzos, en la sepultura que determinase el Prior. Pocas horas más tarde, «en ese mismo día y ante el presente escribano (..) estando como estoy en ánimo de mudar en él algunas cosas» señaló "por vía de Cobdicilio» que la inhumación fuera en la parroquia de San Cosme y San Damián, de la que era «Parroquiana», en la sepultura de los Martínez Solares «en que yaze mi hermana»118.

\section{ANEXo BiBLIOGRÁFICO}

AGO, R., «Destin des cadets et carrière ecclésiastique dans la noblesse italienne du XVII siècle», G. RAVIS-Giordani y M. SEgalen (Dirs.), Les cadets, París, 1994, pp. 231-239.

Alberro, S., «El amancebamiento en los siglos XVI y XVII: un medio eventual de medrar», Familia y poder en Nueva España. Memoria del III Simposio de Historia de las mentalidades, México, 1991, pp. 155-166.

Álvarez Santaló, L. C., «Vivir como un cura». Algunas precisiones cuantitativas respecto al imaginario social sobre el clero en el siglo XVIII», F. J. ARANDA PÉrez (Coord.), Sociedad y élites eclesiásticas en la España Moderna, Cuenca, 2000, pp. 101-147.

Álvarez Santaló, L.C. y García-Bauero GonZÁlez, Antonio, «Riqueza y pobreza del clero secular en la Sevilla del Antiguo Régimen (1700-1834)», Trocadero, 8-9, (1998), Cádiz, pp. 11-47.

Antón Pelayo, J., La sociabilitat epistolar de la familia Burgués de Girona (1799-1803), Girona.

Aragón Mateos, S., «Amos y criados en la Extremadura dieciochesca», Actas del Congreso Internacional «Carlos III y la Ilustración», 1990, Madrid, pp. 403-424.

Aragón Mateos, S., «Notas sobre el clero secular en el Antiguo Régimen. Los presbíteros en el obispado de Coria en el siglo XVIII», Hispania Sacra, 89 (1992), Madrid, pp. 291-334.

Barreiro Mallón, B., Religiosidad y clero en Zamora durante la Edad Moderna, Zamora, 1988.

BARrio Gozalo, M., Estudio socio-económico de la Iglesia de Segovia en el siglo XVIII, Segovia, 1982.

${ }^{118}$ AHPB. PN. Rafael Pérez Romo. Legajo 7234 (1 de noviembre de 1780), folio 575.

Hispania Sacra, LXI

124, julio-diciembre 2009, 649-690, ISSN: 0018-215-X 
BARreneche, O., «Esos torpes deseos». Delitos y desviaciones sexuales en Buenos Aires, 1760-1810», Estudios de historia colonial, 13 (1993), pp. 29-45.

Benítez BAREA, A., «El clero de Medina Sidonia y su entorno en el siglo XVIII», Actas del III Congreso de Historia de Andalucía, Córdoba, 2003, Tomo II, pp. 7-23.

Benito Aguado, M. T., La sociedad vitoriana en el siglo XVIII: el clero, espectador y protagonista, Bilbao, 2001.

Benito Aguado, M. T., «Vigilando las conciencias. El clero al amparo de las cuatro torres», M. R. Porres MARIJUÁn, Vitoria, una ciudad de «ciudades». Una visión del mundo urbano en el País Vasco durante el Antiguo Régimen, Bilbao, 1999, pp. 303-375.

Benlloch Poveda, A., «Jurisdicción eclesiástica en la Edad Moderna: el proceso», E. MARTínez RuIZ, Instituciones de la España Moderna, Madrid, 1996, tomo I, pp. 113-143.

Berthelot De CheSnAy, Ch., «Le clergé diocesain français au XVIII siècle et les registres des insinuation eclesiastique», Revue d' Histoire Moderne et Contemporaine, 10 (1963), París, pp. 231-269.

Blanco DíEZ, A., «Dignidades eclesiásticas burgalesas: los deanes de la Catedral de Burgos», Boletín de la comisión Provincial de Monumentos históricos y artísticos de Burgos, 90, (1945), Burgos, pp. 488-548, 93 (1945), Burgos, pp. 649-655 y 94 (1946), Burgos, pp. 44-48.

Blanco DíEz, A., «Los arcedianos y abades del Cabildo Catedral de Burgos», Boletín de la Real Academia de la Historia, 130 (1952), Madrid, pp. 267-298.

Bouza Álvarez, F., «La correspondencia del hombre práctico. Los usos epistolares de la nobleza española del Siglo de Oro a través de seis años de cartas del tercer conde de Fernán Núñez (1679-1684)», Cuadernos de Historia Moderna, Anejos, 4 (2005), Madrid, pp. 129-154.

Bravo LozAnO, J., «Cura rico/cura pobre. Notas sobre rentas eclesiásticas en el Madrid de fines del siglo XVII», E. MArTínEZ RuIZ, y V. SuÁrez Grimón (Eds.), Iglesia y sociedad en el Antiguo Régimen. III Reunión Científica de la Asociación Española de Historia Moderna, vol. I, Las Palmas de Gran Canaria, 1994, pp. 129-139.

Bravo Lozano, J., Familia busca vivienda-Madrid, 1670-1700-, Madrid, 1992, pp. 104-112.

Brunet, S., Les prêtres des montagnes. La vie, la mort, la foi dans les Pyrénées centrales sous l'Ancien Régime (Val d'Aran et diocèse de Comminges), Aper, 2001. 
Cabeza Rodríguez, A., «Grupos excluidos y formas de asimilación y reproducción social. El ejemplo de la Catedral de Palencia en la época Moderna», J. HERnÁNDEZ FrANCO (Ed.): Familia y poder. Sistemas de reproducción social en España (siglos XVI-XVIII), Murcia, 1995, pp. 101-125.

Candanchú Chacón, M. L., «Actitudes y mentalidades en Alcalá de Guadaira durante el Antiguo Régimen: vida privada y delitos de costumbres», Actas de las III Jornadas de Historia de Alcalá de Guadaira, Alcalá de Guadaira, 1991, pp. 41-51.

CAndanchú Chacón, M. L., «Clérigos del mundo rural sevillano: la Iglesia secular en Alcalá de Guadaira a fines del XVII», Actas de las II Jornadas de Historia de Alcalá de Guadaira, Alcalá de Guadaira, 1989, pp. 15-28.

CANDAnchú Chacón, M. L., «De la obediencia debida: religiosidad y normativa en la archidiócesis hispalense durante la Edad Moderna», Actas del I Encuentro Iberoamericano de Religiosidad popular, Huelva, 2000,

Candanchú Chacón, M. L., «Delito y autoridad eclesiástica en la Sevilla de Carlos III», Actas del Coloquio Internacional «Carlos III y su siglo», Madrid, 1990, II, pp. 183-198.

Candanchú Chacón, M. L., «Delitos, pecado y penas de antaño en el mundo eclesiástico», El siglo que viene, Sevilla, 18-19 (1994), Sevilla, pp. 56-60.

CAndanchú Chacón, M. L., «Devociones y galanteos en la Sevilla del Antiguo Régimen», Acta del I Congreso Internacional del Monacato en España, Portugal y América, 1492-1992, León, 1993, tomo II, pp. 561-562.

Candanchú Chacón, M. L., El clero secular de la Campiña sevillana (1685-1791), Sevilla, 1991.

CAndanchú Chacón, M. L., «El clero secular hispalense a fines del Antiguo Régimen: los problemas de la vocación eclesiástica», de BERNARDO ARES, J. M. (Ed), El Hispanismo Anglonorteamericano: Aportaciones, problemas y perspectivas sobre Historia, Arte y Literatura españolas (siglos XVI-XVIII), Actas de la I Conferencia Internacional «Hacia un nuevo Humanismo», Córdoba, 2001, pp. 309-324.

Candanchú Chacón, M. L., «El clero secular hispalense a fines del Antiguo Régimen: los problemas de la vocación eclesiástica», J. M. BERNARDO ARES (Ed.), Actas de la I Conferencia Internacional «Hacia un nuevo Humanismo», Córdoba, 2001 pp. 309-324.

CANDANCHÚ CHACón, M. L., «Entre lo permitido y lo ilícito: la vida afectiva en los tiempos modernos», XIII Coloquio Internacional de la AEIHM, «La historia de las mujeres: Perspectivas actuales», Barcelona, 2006. 
Candanchú Chacón, M. L., La carrera eclesiástica en el siglo XVIII, Sevilla, 1993.

CANDANChú Chacón, M. L., Los delitos y las penas en el mundo eclesiástico sevillano del XVIII, Sevilla, 1993, en especial las pp. 219-290.

Candanchú Chacón, M. L., «Modeladores de la conducta y el pensamiento: el altar, el confesionario y el púlpito en la Sevilla rural del XVIII. El modelo y su práctica», Actas del Congreso Internacional sobre Iglesia, Estado y Sociedad en España, Francia e Italia. Siglos XVIII-XX, Niza, 1992.

Candanchú Chacón, M. L., «Un mundo perseguido. Delito sexual y justicia eclesiástica en los tiempos modernos», I. ForTEA, J. E. GELABERT y T. A. MANTECÓN (Eds.), Furor et rabies: violencia, conflicto y marginación en la Edad Moderna, Santander, 2002, pp. 403-432.

Cánovas Botía, A., Auge y decadencia de una institución eclesial: el Cabildo Catedral de Murcia en el siglo XVIII. Iglesia y sociedad, Murcia, 1994.

Castillón Cortada, F., «Estructura del Cabildo catedralicio de Lleida durante el siglo XVIII», Esglesia i societat à la Catalunya del segle XVIII, Cervera, 1990, pp. 99-117.

Cobos Ruiz de AdAna, J., «Delincuencia y sexualidad en la Córdoba barroca», El Barroco en Andalucía, II, Córdoba, 1983, pp. 57.

Cobos Ruiz de Adana, J., El clero en el siglo XVII. Estudio de una visita secreta a la ciudad de Córdoba, Córdoba, 1976.

Cobos Ruiz de AdAna, J., «Matrimonio, amancebamiento y bigamia en el Reino de Córdoba en el siglo XVII», El Barroco en Andalucía, II, Córdoba, 1983, pp. 58-59.

Coronas Vida, L. J., «Los miembros del Cabildo de la Catedral de Jaén (1700-1737)», Chronica Nova, 15 (1986-1987), Jaén, pp. 101-126.

CuART Moner, B., «La sombra del arcediano: el linaje oculto de don Lorenzo Galíndez de Carvajal», Stvdia Historica, Historia Moderna, 15 (1996), Salamanca, pp. 135-178.

Cruselles Gómez, J. M., «Los estudiantes de la Valencia preuniversitaria: entre la carrera eclesiástica y la sociedad civil», Estudis, 23 (1997), Valencia, pp. 11-40.

DAUMAS, M., Le syndrome des grieux. La relation père-fils au XVIII e siècle, París, 1990.

Delumeau, J. y Roche, D., Histoire des pères et de la paternité, París, 1990.

DingES, M., «El uso de la justicia como forma de control social en la Edad Moderna», Passim, pp. 47-68. 
Dubert GARCÍA, I., «Alma de cura y cura de almas. Moral y comportamientos eclesiásticos en la Galicia interior durante el Antiguo Régimen (16001830)», Semata, 7-8 (1996), Santiago de Compostela, pp. 379-411.

Dubert García, I., Historia de la familia en Galicia durante la época Moderna, 1550-1830. (Estructura, Modelos hereditarios y Conflictividad), La Coruña, 1992, en especial las pp. 167-184.

Dubert GARcía, I., «La domesticación, la homogeneización y la asimilación de las conductas del clero gallego del Antiguo Régimen a la idealidad del modelo tridentino, 1600-1850», Actas del Congreso «El Antiguo Régimen y la Revolución Liberal», Madrid, 1995, II, pp. 477-497.

DuBERT GARCíA, I., «La huella de la transgresión en el mundo eclesiástico de la Galicia interior, 1600-1830», Compostellanum, (1994), Santiago de Compostela, pp. 371-389.

Dubert García, I., «Los comportamientos del clero urbano en Galicia: el ejemplo de Santiago de Compostela en el siglo XVIII», Compostellanum, 31 (1986), Santiago de Compostela, pp. 443-456.

Dubert GARcíA, I., «Los comportamientos sexuales premaritales en la sociedad gallega del Antiguo Régimen», Stvdia Histórica, Historia Moderna, 9 (1991), Salamanca, pp. 117-142.

DURAES, M., «Heranças: solidaridades e conflictos na casa camponesa minhota (sec. XVIII-XIX)», Revista da Faculdade de Letras da Universidade de Coimbra, 76 (2000), Lisboa, pp. 155-186.

Duraes, M., «No fim, nao somos iguales», Revista de Demografía Histórica, 10/3 (1992), Barcelona, p. 125-142.

ENCISO RoJAS, D., «Y dijo que lo conoce de vista, trato y comunicación». Vigilar para denunciar», Casa, vecindario y cultura en el siglo XVIII. Memoria del VI Simposio de Historia de las Mentalidades. Seminario de Historia de las Mentalidades, México, 1998, pp.131-141.

FAlCón Gómez SÁNCHEZ, F. J., «El matrimonio clandestino de María Isabel Cavero. Conflicto entre amor, leyes e Iglesia en Truxillo de Perú a fines del siglo XVIII (1794)», Nuevo Mundo Mundos Nuevos, 7 (2007). http://nuevomundo.revues.org/document3352.html

FArge, A., «Familias. El honor y el secreto», P. ArIEs y G. Duby (Dirs.), Historia de la vida privada, t. VI., Madrid, 1992, pp. 183-219.

FATjó Gómez, P., «Aproximación a una élite institucional de la Cataluña Moderna: los capitulares de la Seo de Barcelona en el siglo XVII», Pedralbes, 13/2 (1993), Barcelona, pp. 149-162. 
FERNÁNDEZ CoRdero, M. J., «Concepción del mundo y de la vida en los eclesiásticos del siglo XVIII a través de la predicación. Ilustración, pensamiento cristiano y herencia barroca», Cuadernos de Historia Moderna, 10 (19891990), Madrid, pp. 81-101.

FERNÁNDEZ DíAz, R., «La clerecía catalana en el Setecientos», Esglesia i societat à la Catalunya del segle XVIII, Cervera, 1990, pp. 23-118.

García GonZÁlez, F., «Casa y vecindad. Relaciones de parentesco, amistad y vecindad en una ciudad de la España meridional del Antiguo Régimen: Alcaraz en el siglo XVIII», Casa, vecindario y cultura en el siglo XVIII. Memoria del VI Simposio de Historia de las Mentalidades. Seminario de Historia de las Mentalidades, México, 1989, pp. 35-53.

García GonzÁlez, F., «De un lugar de La Mancha a la Sede Primada de Toledo: la familia del cardenal Monescillo en el Antiguo régimen», Obradoiro de Historia Moderna, 14 (2005), pp. 175-200.

García Mouton, P., «Religiosidad popular en la picaresca», L. C. Álvarez SANTALÓ (Coord.): La religiosidad popular, tomo II, Madrid, 1989, pp. 146-153.

Garmendía Arruebarrena, J., Tomás Ruiz de Apodaca, un comerciante alavés con Indias (1709-1767), Vitoria, 1990.

GARRIDO ARCE, E., «La imposible igualdad. Familia y estrategias hereditarias en la Huerta de Valencia a mediados del siglo XVIII», Boletín de la Asociación Española de Demografía Histórica, 10/3 (1992), Barcelona, pp. 83-104.

GiMéNEZ LóPEZ, E., «El factor familiar en el cursus honorum de los magistrados españoles del siglo XVIII», J. HernáNDEZ FrAnCo (Ed.): Familia y poder. Sistemas de reproducción social en España (siglos XVI-XVIII), Murcia, 1995, pp. 139-163.

Gómez NAVARro, S., «Caracterización del clero catedralicio cordobés del Antiguo Régimen», Hispania Sacra, 52 (2000), Actas del I Congreso de Historia de la Iglesia y el Mundo Hispánico, Madrid, pp. 259-263.

GonZÁlez CruZ, D., Familia y educación en la Huelva del siglo XVIII, Huelva, 19, pp. 104.

González Marmolejo, J. R., «Algunos grupos desviantes en México Curas solicitantes durante el siglo XVIII», Familia y sexualidad en Nueva España. Memoria del I simposio de historia de las mentalidades, México, 1982, pp. 258-266.

GonzÁlez Marmolejo, J. R., «Clérigos solicitantes, perversos de la confesión», De la santidad a la perversión o de por qué no se cumplía la ley de Dios en la sociedad novohispana, México, 1986, pp. 239-252.

Hernández Bermejo, M. A., La familia extremeña en los tiempos Modernos, Badajoz, 1990, pp. 317-325. 
HERNÁNDEZ FRANCO, J., «El padre. El rey de la casa», La aventura de la historia, 63 (2004), «La familia en España», Madrid, pp. 76-79.

Imízcoz BeunZA, J. M., «El patrocinio familiar. Parentela, educación y promoción de las élites vasco-navarras en la monarquía borbónica», F. CHACóN JIMÉNEZ y J. HERnÁNDEZ FRANCO (Eds.): Familia, poderosos y oligarquías, Murcia, 2001a, pp. 93-130.

Imízcoz Beunza, J. M. (Dir.), Elites, poder y red social. Las élites del País Vasco y Navarra en la Edad Moderna, Bilbao, 1996.

Imízcoz BeunzA, J. M., «Patronos y mediadores. Redes familiares en la Monarquía y patronazgo en la aldea: la hegemonía de las elites baztanesas en el siglo XVIII», J. M. Imízcoz Beunza (Dir.), Redes familiares y patronazgo. Aproximación al entramado social del País Vasco y Navarra en el Antiguo Régimen (siglos XV-XIX), Bilbao, 2001b, pp. 225-262.

Imízcoz Beunza, J. M., Guerrero, R. y Castellano de Gastón, G., Entre la aldea y la Corte. Correspondencia epistolar de los Gastón de Iriarte en la hora Navarra del XVIII, Vitoria, 2002.

IRIGOYEN LóPEZ, A., Entre el cielo y la tierra, entre la familia y la Institución. El Cabildo de la Catedral de Murcia en el siglo XVII, Murcia, 2000.

IRIGOYEN LóPEZ, A., «Servicio doméstico de clérigos y clérigos en el servicio doméstico. El caso de Murcia en la Edad Moderna», http://www.ugr.es/ $\sim$ adeh/comunicaciones/irigoyen_a.pdf.

JoRdi FernándeZ, A., «Els canonges de la Seu de Tarragona durant el segle XVIII: aproximació al seu estudi», Esglesia i societat à la Catalunya del segle XVIII, Cervera, 1990, pp. 255-265.

JuLIA, D., «Le clergé paroissial dans le diocése de Reims à la fin du XVIIIe siècle», Revue d' Histoire Moderne et Contemporaine, 12 (1966), París, pp. 195-216.

LANGUE, F., «De la munificencia a la ostentación. La nobleza de la ciudad de México y la cultura de la apariencia (siglos XVII-XVIII)», Seminario Interuniversitario sobre América española, París, 2005 y Caravelle, 64 (1995), pp. 49-75.

López Arévalo, J. R., Un Cabildo Catedral de la Vieja Castilla. Ávila: su estructura jurídica, siglos XIII-XX, Madrid, 1966.

LóPEZ LóPEZ, R., «Aproximación al clero urbano ovetense», Cuadernos de Investigación Histórica, 11 (1989), Madrid, pp. 111-129.

Lorenzo Pinar, F. J., Amores inciertos, amores frustrados. (Conflictividad y transgresiones matrimoniales en Zamora en el siglo XVII), Zamora, 1999.

LoRENZo PINAR, F. J., «La familia y la herencia en la Edad Moderna zamorana a través de los testamentos», Stvdia Historica, Historia Moderna, 9, Salamanca, 1991, p. 179-196. 
Lozano Armendares, T., «Y es de pública voz y fama». Conflictos entre vecinos en el siglo XVIII», Casa, vecindario y cultura en el siglo XVIII. Memoria del VI Simposio de Historia de las Mentalidades. Seminario de Historia de las Mentalidades, México, 1989, pp. 117-130.

Lugo, Y., «Abarragamientos dieciochescos (el concubinato en la provincia de Caracas en el siglo XVIII)», Tierra Firme, 62 (1998), pp. 227-238.

MaIZA OxCoIDI, C., «Injuria, honor y comunidad en la sociedad Navarra del siglo XVIII», Príncipe de Viana, 197, (1992), Pamplona, pp. 685-695.

Mantecón, T. A., Conflictividad y disciplinamiento social en la Cantabria rural del Antiguo Régimen, Santander, 1997, pp. 388-401.

Mantecón Movellán, T. A., «Mujeres forzadas y abusos deshonestos en la Castilla moderna», Manuscrits, 20 (2002), Barcelona, pp. 157-185.

MARTín BAÑos, P., «Familia, retórica, cortesana: disfraces de la carta en los tratados epistolares renacentistas», Cuadernos de Historia Moderna, Anejos, 4 (2005), Madrid, pp. 15-30.

Mirelarena Peña, F., «Estructuras familiares, ciclo de vida, composición del hogar y mano de obra extrafamiliar en el sen o de los grupos domésticos de una ciudad tradicional: el ejemplo de Pamplona en 1786», Boletín de la Asociación Española de Demografía Histórica, 12/3 (1994), Barcelona, pp. 127-147.

Molas Ribalta, P., «Manteístas en Valencia, 1707-1759», Anales de la Universidad de Alicante, Revista de Historia Moderna, 13/-14 (1995), Alicante, pp. 31-49.

Morgado García, A., «El alto clero gaditano durante el Antiguo Régimen (1600-1833)», Stvdia Histórica, Historia Moderna, 16 (1997), Salamanca, pp. 223-255.

Morgado García, A., El clero gaditano a fines del Antiguo Régimen, Cádiz, 1989.

Morgado García, A., «El clero gaditano en el siglo XVIII», Actas del Congreso Internacional sobre «Carlos III y la Ilustración», II, Madrid, 1989, pp. 389-402.

Morgado García, A., El estamento eclesiástico y la vida espiritual en la diócesis de Cádiz en el siglo XVII, Cádiz, 1996.

Morgado García, A., Iglesia y sociedad en el Cádiz del siglo XVIII, Cádiz, 1989.

Morgado García, A., Ser clérigo en la España del Antiguo Régimen, Cá$\operatorname{diz}, 2000$. 
Morgado García, A., «Vida de canónigo. Percepción, origen y status de vida del alto clero durante el Antiguo Régimen», F. J. ArANDA PÉREZ (Coord.), Sociedad y élites eclesiásticas en la España Moderna, Cuenca, 2000, pp. 77-99.

OrTEGa LóPez, M., «Violencia familiar en el pueblo de Madrid durante el siglo XVIII», Cuadernos de Historia Moderna, 31 (2006), Madrid, pp. 7-37.

Peñafiel RAmón, A., Mujer, mentalidad e identidad en la España Moderna (siglo XVIII), Murcia, 2001, pp. 102-114.

PÉREZ GARCÍA, P., «La criminalización de la sexualidad en la España Moderna», Passim, pp. 355-402.

PÉrez Muñoz, I., Pecar, delinquir y castigar: el tribunal eclesiástico de Coria en los siglos XVI y XVII, 1992, Cáceres, pp. 100.

Phan, M. C., Les amours illégitimes. Histoire de séduction en Languedoc (1676-1786), París, 1986.

Pino Iturrieta, E., Contra lujuria, castidad. Historias de pecado en el siglo XVIII venezolano, Caracas, 1992.

Pino ItURrieta, E. (Coord.), Quimeras de amor, honor y pecado en el siglo XVIII venezolano, Caracas, 1994.

Plongeron, B., La vie quotidienne du clergé français au XVIIIe siécle, París, 1974.

Polo Rodríguez, J. L., «Estudiantes manteístas salmantinos en la Universidad de Salamanca de la primera mitad del siglo XVIII», Stvdia Historica, Historia Moderna, 9 (1991), Salamanca, pp. 23-41.

Quintana Andrés, P. C., A Dios rogando, y con el mazo dando. Fe, poder y jerarquía en la iglesia canaria. El Cabildo Catedral de Canarias entre 14831820, Las Palmas de Gran Canaria, 2003.

QuintANA ANDrÉs, P. C., «Actitudes del alto clero canario ante la muerte: preeminencia, ostentación social y conflictividad durante la Edad Moderna», El museo Canario, 61 (2996), pp. 181-216.

QuintANA ANDRÉS, P. C., «La muerte como reflejo de la estructura socioeconómica durante el Antiguo Régimen: el ejemplo de los prebendados del cabildo Catedral de Canarias», Boletín Millares Carlo, 24-25 (2005-2006), pp. 51-85.

Rey CASTElaO, O., «El clero urbano compostelano a fines del siglo XVIII: mentalidades y hábitos culturales», La historia social de Galicia en sus fuentes de protocolos, Santiago de Compostela, 1981, pp. 495-519.

Rodríguez Jiménez, P., Cabildo y vida urbana en el Medellín colonial, 1675-1730, Medellín, 1992. 
RodrígueZ JiméNeZ, P., «El amancebamiento en Medellín, siglos XVIIIXIX», Seducción, amancebamiento y abandono en la colonia, Santa Fe de Bogotá, 1991, pp. 73-93.

RodríGUEZ JiMÉNEZ, P., Seducción, amancebamiento y abandono en la Colonia, Bogotá, 1991.

RodríGuez SÁnCHEZ, A., «El padre de familia. La patria potestad en el Antiguo Régimen», Chronica Nova, 18 (1990), Granada, pp. 365-380.

RodRíGUEZ SÁNCHEZ, A., «Un proceso sin sentencia. Acusado y acusadores en la diócesis de Coria en 1591», Espacio, Tiempo, Forma, Revista de la Facultad de Geografía e Historia, 4 (1989), pp. 501-550.

SAEZ, R., «La transgression de l' interdit amoureux: le prêtre, la femme et l' enfant dans l' archevêché de Tolède (1565-1620)», A. REDONDO, Amours legitimes, amours illégitimes en Espagne (XVIe-XVII ${ }^{e}$ siécles), Paris, 1985, pp. 93-100.

SAmudio, E., «Un matrimonio clandestino en Mérida en el ocaso del período colonial», Revista Solar, 2 (1990), Mérida (Venezuela).

SÁncheZ, A., «Pecados secretos, públicas virtudes: el acoso sexual en el confesionario», Revista Andina, 14/1 (1996), pp. 121-147.

SÁnchez GonzÁlez, R., «El clero rural del arzobispado de Toledo en el Seiscientos: distribución, formación y conducta», Hispania Sacra, 46, 1994, pp. 427-447.

SÁNCHEZ GONZÁLEZ, R., «El clero secular en los territorios de Órdenes: vita et moribus y tensiones con la Dignidad Arzobispal», J. LóPEZ-SALAZAR PÉREZ (Coord.), Las Órdenes militares en la Península Ibérica, vol. II. Edad Moderna, Cuenca, 2000, pp. 2149-2177.

SÁNCHEZ GonZÁLEZ, R., «Religiosidad barroca y sentimientos ante la muerte en el Cabildo catedralicio de Toledo», Stvdia Historica, Historia Moderna, 18 (1998), Salamanca, pp. 299-320.

SÁnCHEZ GonZÁLEZ, R., «Señorío y justicia en los Montes de Toledo: las causas de amancebamiento en la Edad Moderna», F. J. ARANDA PéreZ (Coord.), El mundo rural en la España Moderna, Actas de las VII Reunión Científica de la Fundación Española de Historia Moderna, Cuenca, 2004, pp. 1285-1293.

SANZ DE LA HigueRA, F. J., «Cebada, mulas, caballos, carruajes y habas. La Catedral de Burgos en el Setecientos», Hispania Sacra, 116 (2005a), Madrid, pp. 559-588.

SANZ de la HigueRA, F. J., «En casa [, cama] y compañía». Yacer a lomos del XVIII en los hogares eclesiásticos burgaleses», Hispania Sacra, 118 (2006a), Madrid, pp. 545-577. 
SanZ De La Higuera, F. J., «Seminario de San Nicolás (Burgos, 1743): una rectoría apetecible, un litigio aborrecible», Boletín de la Institución Fernán González, 232 (2006b), Burgos, pp. 149-177.

SANZ DE LA Higuera, F. J., «Vestiduras, hábitos, papeletas y ataúdes. El cadáver clerical en el Burgos del XVIII», Huarte de San Juan, Geografía e Historia, 12 (2005b), Pamplona, pp. 215-245.

SARrión Mora, A., Sexualidad y confesión. La solicitación ante el tribunal del Santo Oficio (siglos XVI-XIX), Madrid, 1994.

Schilling, H., «El disciplinamiento social en la Edad Moderna: propuesta de indagación interdisciplinar y comparativa», I. ForteA, J. E. GElaberT y A. MANTECÓN (Eds.), Furor et rabies: violencia, conflictos y marginación en la Edad Moderna, Santander, 2002, pp. 17-45.

Seidel Menchi, S. E. y Quaglioni, D. (Eds.), Trasgressioni. Seduzione, concubinato, adulterio, bigamia (XIV-XVIII secolo), Bolonia, 2004.

TESTÓN NúÑEZ, I., Amor, sexo y matrimonio en Extremadura, 1985, Badajoz.

Testón NúÑEz, I. y Santillana Pérez, M., «El clero cacereño durante los siglos XVI al XVIII: comportamientos y mentalidad», Actas de las II Jornadas de Metodología y Didáctica de la Historia, Cáceres, 1983, pp. 463-472.

TORREMOCHa HERnándeZ, M., «Las noches y los días de los estudiantes universitarios (posadas, mesones y hospederías en Valladolid, siglos XVIXVIII)», Anales de la Universidad de Alicante, Revista de Historia Moderna, 10 (1991), Alicante, pp. 43-70.

TORREMOCHA HERNÁNDEZ, M., Ser estudiante en el siglo XVIII. La Universidad vallisoletana de la Ilustración, Valladolid, 1989.

VAlENCIA, A., «El chisme y el escándalo en la sociedad colonial», Estudios Sociales, 3 (1988), pp. 33-45.

VÁzquez Lesmes, J. R., Córdoba y su Cabildo catedralicio en la modernidad, Córdoba, 1987.

Villacorta Rodríguez, T., El Cabildo Catedral de León. Estudio históricojurídico, siglo XII-XIX, León, 1974.

Villafuertes García, L., «Padres e hijos. Voluntades en conflicto (México, siglo XVIII)», Seminario de historia de las mentalidades. Familia y poder en Nueva España. Memoria del III simposio de historia de las mentalidades, México, 1991, pp. 133-142.

YASSER, L., «Abarragamientos dieciochescos: el concubinato en la provincia de Caracas en el siglo XVIII», Tierra Firme: Revista de Historia y Ciencias Sociales, 16 (1998), Caracas, pp. 227-237. 